\title{
Price impact of bond supply shocks: Evidence from the Eurosystem's asset purchase program
}

\author{
William Arrata ${ }^{1}$, Benoît Nguyen ${ }^{2}$ \\ Working Paper 623, March 2017
}

\begin{abstract}
We use new daily security-level data and test the impact of the Eurosystem's Public sector purchase program (PSPP) on bond returns in the French bond market. We investigate three possible types of supply shocks: related to the cumulative past purchases ("stock") since the start of the program, the transactions themselves on the day of the purchase ("flow"), and the variation in the expected total size of the program ("expected stock"). Our results show that having purchased $10 \%$ of a bond outstanding correlates with a decrease in yield of about -13 bps to -26 bps on average in the first year of implementation of the program, with bigger effects in the most illiquid segments. Set aside very particular conditions, we don't find any significant supplemental effect from flows, presumably in line with the market neutrality objective of the Eurosystem. We then focus on the European bond sell-off period during the spring-summer 2015 , and show it was associated with a reduction of the total size of the program expected by market participants, suggesting an Odyssean vs Delphic type of issue for the communication on asset purchases.
\end{abstract}

Keywords: QE, asset purchase programs, bond supply, unconventional monetary policy

JEL classification: E52, E58, G11, G12

\footnotetext{
${ }^{1}$ Banque de France, Market operations Department - Contact: william.arrata@banque-france.fr

${ }^{2}$ Banque de France, Monetary Policy and Financial Research Department - University Paris 1 PantheonSorbonne (CES) - Contact (corresponding author): benoit.nguyen@banque-france.fr

Working Papers reflect the opinions of the authors and do not necessarily express the views of the Banque de France. This document is available on publications.banque-france.fr/en

Les Documents de travail reflètent les idées personnelles de leurs auteurs et n'expriment pas nécessairement la position de la Banque de France. Ce document est disponible sur publications.banquefrance.fr
} 


\section{NON-TECHNICAL SUMMARY ${ }^{3}$}

In a context of prolonged low inflation, the Eurosystem ${ }^{4}$ engaged in January 2015 in a large scale asset purchase program focused on government bonds (Public Sector Purchase Program, thereafter PSPP), with effective purchases starting in March 2015. The Eurosystem purchases Euro area government, para-public and supranational debt, on top of existing purchases of ABS and covered bonds, at an initial pace of 60 billion euros per month. The program was announced in an open-ended way, initially intended to be carried out until end-September $2016^{5}$ and "until we see a sustained adjustment in the path of inflation" (Jan 2015 ECB Governing Council Press Conference).

This paper brings new evidence on the transmission mechanisms of PSPP purchases based on the first year of implementation, using daily security-level data and PSPP purchase transactions in the French bond market. French government bond market is the second largest in terms of outstanding amounts in the euro area, and presents a diversity of instruments (nominal, inflation linked, local government, public agencies...), fairly representative of the diversity of the European debt. PSPP purchases are split between each euro area jurisdiction following the capital key the participation of each national central bank in the ECB capital - and French government bond market is also the second largest market for PSPP purchases.

To our knowledge, this is the first paper exploiting security-level data to analyze PSPP purchase program. Our methodology is similar to the one employed by Federal Reserve's economists D'Amico and King (2013), and Bank of England's Joyce et al. (2010), taking advantage of our data both in panel and in cross-section to disentangle the different price impact channels of asset purchases.

More precisely, we test the impact of the Eurosystem's PSPP on bond returns along three ways: the impact of the cumulated past purchases since the start of the program (what literature generally names "stock": Is cross-section of bond returns affected by the share of supply removed by PSPP?), the price impact of actual transactions the day of the purchase ("flow": Do bonds over-perform the day they were purchased?), and the variation in the expected total size of the program ("expected stock": do variations in the total expected size of purchases matter?).

We might observe "stock" effects if there is imperfect substitutability across bonds and preferred-habitat type of frictions. Our results support this view. Our findings suggest that the cross-section of bond returns, one year after the beginning of purchases, is significatively affected by the stock of PSPP purchases. The impact is larger for longer maturities and inflationlinked bonds, and in the range of other estimations in the literature. As purchases might be

\footnotetext{
${ }^{3}$ We thank Vikas Agarwal, Philippe Andrade, Stefania D'Amico, Régis Breton, Vincent Bignon, Paul Hubert, Hubert Kempf, Hervé Le Bihan, Antoine Martin, Julien Matheron, Benoit Mojon, Guillaume Plantin, Imene Rahmouni-Rousseau, Johannes Stroebbel and Miklos Vari. We are grateful to Banque de France colleagues from research and market operations and in particular to Franck Auberger, Jean-Sébastien Cagnioncle, Jan Eric Fillieule, Elie Lewi and Caroline Souchon for their comments. All remaining errors are ours.

${ }^{4}$ Eurosystem refers to the ECB + National central banks (NCBs) and is the relevant level for the implementation of the asset purchase program.

${ }^{5}$ This was subsequently adjusted to 80 bn Eur/month in March 2016, and ultimately extended until December 2017.
} 
themselves determined with respect to yields, we propose an instrumental variable to correct for the potential endogeneity bias. We take advantage of the program's rules on the type of bonds that the Eurosystem would avoid in order not to impair market functioning, such as cheapest-todeliver bonds underlying futures contracts, or bonds that are scarce in the repo market.

A "flow" effect arises when a central bank asset purchase transaction is large enough to create a local distortion in the yield curve that is not fully arbitraged. PSPP as opposed to other QE programs was explicitly intended to minimize "unintended consequences, which can be ensured by obeying the concept of market neutrality. We do want to affect market prices but we will not suppress the price discovery mechanism" (Coeuré, "Embarking on public sector asset purchases" 10 March 2015). Our results point out to almost inexistent flow effect, at least from the French bond market perspective and at the early stage of the program. We supplement this finding by showing how this concept of "market neutrality" is reflected into the PSPP implementation, which appears to be very singular compared with operational implementation of QE by the Federal Reserve or the Bank of England.

Lastly, we look at expected total size of purchases. An episode particularly striking is the European government bonds sell-off that occurred between April and July 2015. During this period, European government bonds yields experienced a rise of about +100 basis points, only two months after the start of purchases. The episode resembles the sell-off of November 2010 in the US on the announcement of QE2; an episode that is explained by Federal Reserve's officials by markets scaling down their expectations about the total size of QE purchases. To see whether this type of story holds in the Euro area, we extract a proxy of expectations of total size of PSPP from poll data to test whether this is the case. Our results provide new evidence on the importance of the total expected stock of purchases, and show the European bond sell-off is associated with a reduction in the total size of the program expected by market participants.

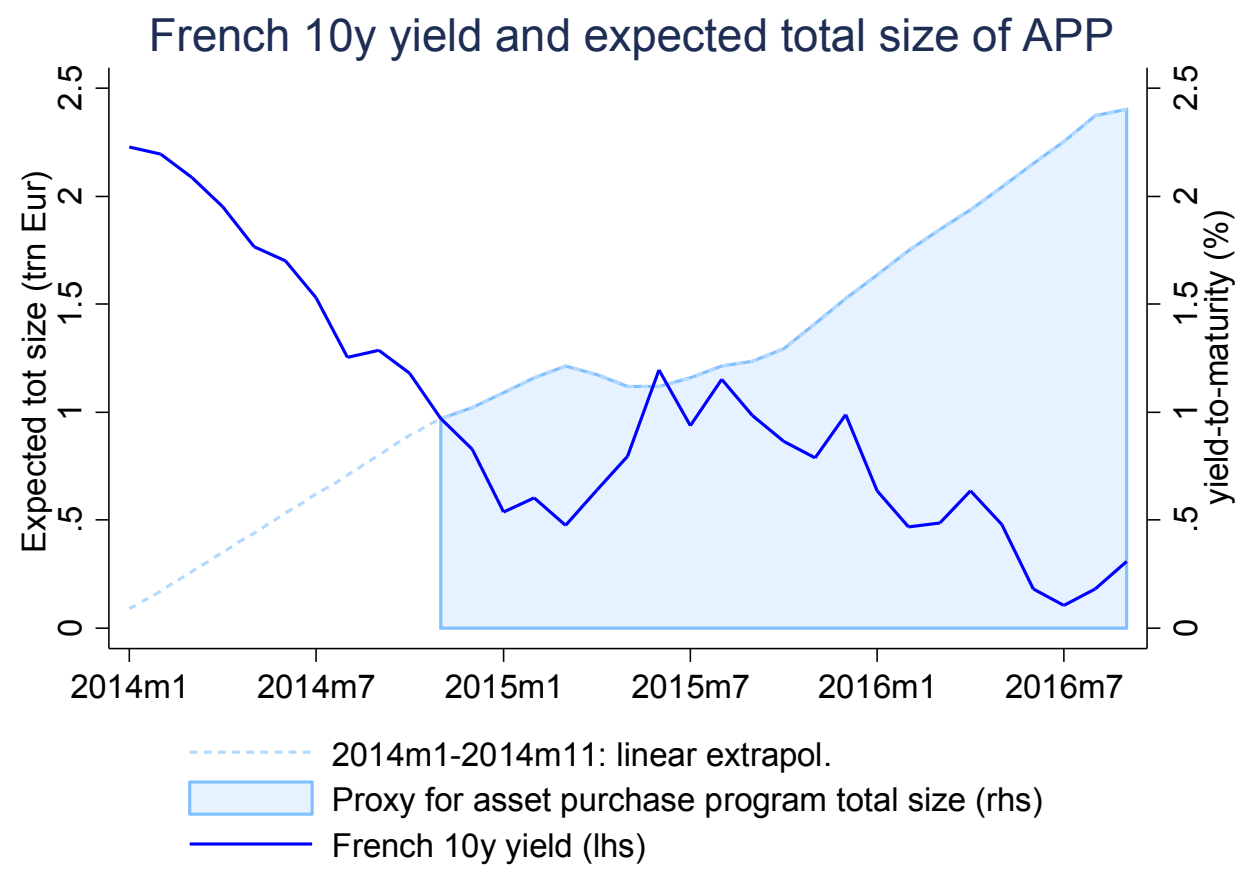




\section{RÉSUMÉ}

\section{EFFETS PRIX DES CHOCS SUR LES ENCOURS OBLIGATAIRES : UNE ANALYSE DU PROGRAMME}

\section{D'ACHAT DE TITRES DE L'EUROSYSTÈME}

Nous exploitons de nouvelles données titre par titre pour tester l'impact du programme d'achats de titres publics de l'Eurosystème (PSPP) sur les rendements des obligations françaises. Nous nous intéressons à trois types de chocs : relatifs aux achats cumulés passés depuis le début du programme ("stock »), aux transactions elles-mêmes le jour des achats (« flux »), ainsi qu'à la variation de la taille totale anticipée du programme (" stock anticipé »). Nos résultats suggèrent qu'acheter $10 \%$ de l'encours d'une obligation est corrélé avec une baisse de son taux de l'ordre de -13 à -26 bps, en moyenne, et pour la première année du programme, avec des effets plus importants pour les segments des plus illiquides. Hors certaines conditions très particulières, nous ne trouvons pas d'effets supplémentaires provenant des transactions, ce qui est possiblement lié à l'application d'une règle de neutralité de marché par l'Eurosystème. Enfin, nous montrons que l'épisode de remontée brutale des taux Européens du printemps-été 2015 est associé à une réduction de la taille totale anticipée du programme d'achat par les participants de marché, ce qui suggère une tension entre communication odysséenne ou delphique des programmes d'achats de titre.

Mots-clés : QE, programmes d'achats d'actifs, marché obligataire, politiques monétaires nonconventionnelles 


\section{Introduction}

Starting in March 2015, Eurosystem sovereign bonds purchase program is associated with record low levels for yields, pushing down core Euro area 10 year yields close to - or even below - zero. Yet, after one year of implementation $^{1}$, yields stood in fact almost at the same levels than they were before the start of purchases. More surprisingly, between end-April 2015 and March 2016, 10 year yields were indeed less accommodative than they were in March 2015, as shown in Figure 1. Indeed, yields rose sharply by about +100 basis points between 20th April 2015 and 8th July, as a result of a bond sell-off whose interpretation is still particularly unclear $^{2}$.

Figure 1: French 10y nominal yield (Bloomberg)

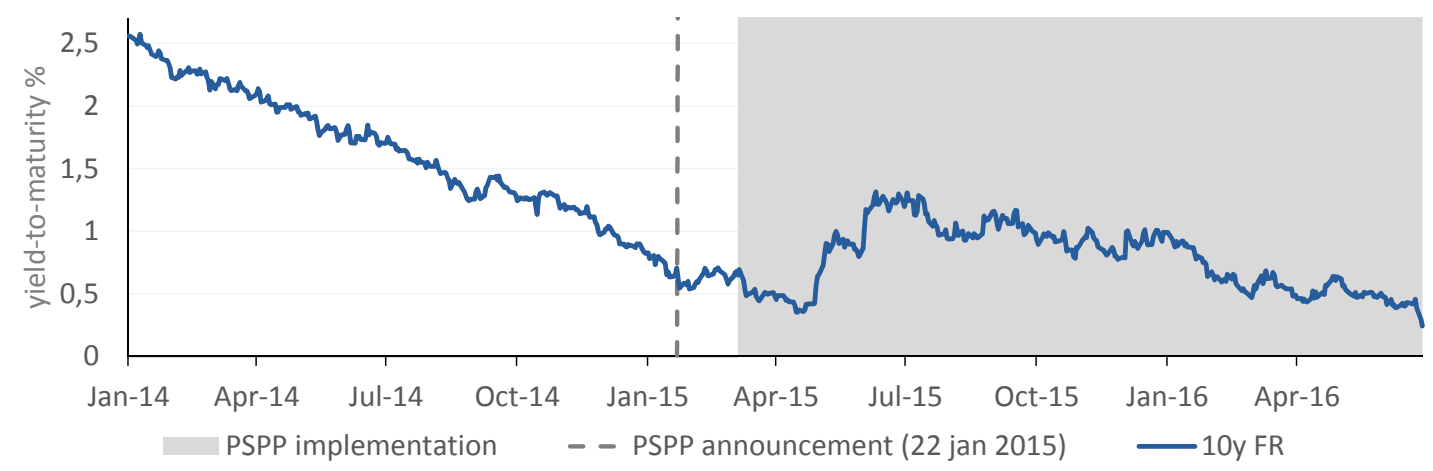

Such a rise in yield at the early stage of an ongoing asset purchase program also seems to be not unique: another example is the rise in US Treasuries yields that immediately followed the announcement of the second round of large scale asset purchase ("QE2") by the Federal Reserve in November 2010. This suggests rising yields might be not coincidental in the course of unconventional monetary policy implementation. These two episodes of bond sell-off were economically non-neutral as yields reversed months of previous decrease ahead of asset purchases announcement ${ }^{3}$. As a result, bond portfolios incurred sizeable losses that could have financial stability implications, at the very moment the central bank aimed at reducing uncertainty and ensuring the proper transmission of its accommodative stance.

Literature on quantitative easing developed around the channels explaining the negative correlation between bond supply and bond yields, generally capturing bond yield changes around key policy announcements or looking at the respective impact of the share of bond supply purchased by the central bank on yields cross-section (generally called stock effects) and the effect of QE transactions themselves (flows effects). Literature is less clear, though, about the reasons why bond yields would actually increase in the presence of the central bank as a large and steady buyer. In the US QE2 case Janet Yellen at the time Vice-Chair of the Fed explained that "the back-up in yields in part reflected a scaling down of expectations" of market participants about "the ultimate size" of the program. Chairman Ben Bernanke made a similar point few months later: "Yields [...] initially declined markedly as markets priced in prospective Fed purchases; these

\footnotetext{
${ }^{1}$ Hereafter, one year refers to the 9th March 2015-9th March 2016 period.

${ }^{2}$ It is sometimes nicknamed "Bund tantrum". BIS notes for instance in a CGFS paper that "In the absence of a specific trigger, market commentary suggests that a number of factors may have contributed to (...) the yield reversal." BIS (2016)

${ }^{3}$ To put it in perspective, both episodes magnitude (about $+100 \mathrm{bps}$ ) are close to the magnitude of the "taper tantrum" episode of 2013. See for instance Neely (2014) or Eichengreen and Gupta (2014).
} 
yields subsequently rose, however, as investors became more optimistic about economic growth and as traders scaled back their expectations of future securities purchases." 4

This view suggests that a powerful - and two-edged - channel of QE is the expectations made by market participants over the total size of the central bank's purchases. Is this kind of story - markets scaling down their expectations of total size of purchases - also applicable to the European sell-off of April 2015 ? While there is no clear answer on the actual triggers of the sell-off, a repricing partly catalyzed by revision of the expectation of total size of the asset purchase program seems plausible ${ }^{5}$. Talks about a possible premature end of the program, for different reasons, from technical (difficulties for the Eurosystem to source the bonds, negative rates...) to political ones (divergence among the Governing Council members about the opportunity to end purchases sooner than initially announced) might have reinforced this uncertainty. We provide details in Annex D.

More generally, this suggests that asset purchases affect bond yields through an interplay of different types of supply shocks, related to both actual and expected supply shocks in the bond market. In this paper, we investigate the effect of supply shocks along these three ways: whether removing stock of a bond correlates with a permanent move in its price, whether flows (ie. each transaction) are correlated with a price impact on the day of purchase, and whether the European bond sell-off can be associated with a downward revision of the expected purchases. To do so, we collect new daily data from the French sovereign debt market, together with security-level PSPP transactions for the first year of the Eurosystem's asset purchase program (9th March 2015 - 9th march 2016). To our knowledge, we are the first to use these daily frequency granular data, which allow us to exploit both cross sectional and panel evidence of the transmission of PSPP. We also extract time-varying expectations of the total size of PSPP to test whether variations in these expectations are associated with the sell-off, as it is alleged in the US case.

This paper is related to several strands of the literature on the links between asset supply and asset price in the context of central banks asset purchases. A large trend of macroeconomic literature was traditionally unsupportive of any effects of central bank asset purchases, following the irrelevance proposition for open market operations formulated by Wallace (1981) ${ }^{6}$. More recent works from Eggertsson and Woodford (2003) and Curdia and Woodford (2010) allow for a price impact of open market operations, but only to the extent they signal the accommodative stance of monetary policy. This is at odds, however, with evidence accumulated for long of the impact of public debt supply and maturity structure on yields (Bernanke et al. (2004) and Garbade and Rutherford (2007) document the impact on yields of US Treasury buybacks policy in 2001 for instance) or the non-neutrality of the debt holding structure (Reinhart and Sack (2000) Warnock and Warnock (2005), Carvalho and Fidora (2015) or Koijen et al. (2016)).

On the other hand, finance literature has acknowledged the impact of quantities - ie. the impact of purchases per se - on price by considering departure from pure expectation hypothesis. Such impact arises from imperfect substituability between assets (Tobin $(1958,1969)$ Andrés et al. (2004)), the existence of preferred habitat and limits to arbitrage (Vayanos and Vila, 2009; Vayanos and Gromb, 2010; Greenwood and Vayanos, 2014). They allow for an effect of purchases themselves besides the signaling predicted by

\footnotetext{
${ }^{4}$ Chairman Ben S. Bernanke, at the National Press Club, Washington, D.C. February 3, 2011

${ }^{5}$ BIS in the same CGFS paper "One factor is uncertainty regarding the implementation of the Eurosystem's Public Sector Purchase Programme (PSPP), including its impact on the availability of securities for trading that the ECB and national central banks were expected to purchase on a large scale."

${ }^{6}$ An exception is Chamley and Polemarchakis (1984), in which the authors consider non-neutrality of nominal asset purchases when money provides additional services on top of store-of-value function.
} 
macroeconomic theory. In models a la Vayanos and Vila (2009), Hamilton and Wu (2012) Altavilla et al. (2015), Hayashi (2016), quantities affect price depending on frictions in portfolio rebalancing and on the arbitrage activity. In the two extreme cases predicted by this class of models, purchasing a bond would either have an impact only on its own price (pure "local supply"), or on the contrary affect all bond prices through the whole term structure by removing an overall quantity of duration that was borne by private markets (pure "duration risk"). This debate on whether asset purchases should impact primarily purchased securities or not is summarized by Cochrane $(2008,2011)$.

This paper is particularly related, lastly, to the empirical literature that tried to disentangle the precise types of supply shock through which asset purchases affect price, a way also to test some of the aforementioned theories. We borrowed to the empirical methodology developed by Joyce et al. (2010), D'Amico and King (2013), Doran et al. (2013), Trebesch and Zettelmeyer (2014), Eser and Schwaab (2016). Most of them used cross section and daily frequency panel data and focused on stock and flows effects of central banks asset purchases. They found evidence of an effect of stock purchased on bond prices, while supplemental effects from flows remain generally small. As noted by Altavilla et al. (2015), this repeated analysis on several rounds of QE by other central banks suggest that asset purchases also have a greater price impact in times of financial stress, a point also made by Krishnamurthy and Vissing-Jorgensen (2011).

Our contribution is threefold. First, we bring new facts on the European asset purchase programs and investigate the transmission channels of PSPP at works in the European bond market. Our results support the existence of stock effects - suggesting local supply channel is at play on top of duration risk channel but found almost no effect from the transactions themselves, at odds with other QE programs. Second, we link these results to differences of implementation of asset purchases between central banks and show the purchase strategy implemented by the Eurosystem is likely to have limited further the possibility of flows effects. Third, we construct a new measure of time-varying expected total size of asset purchases to shed light on the European sell-off period. We found that this period is associated with a reduction of about -100 bn Euros in the expected total size of PSPP.

The remainder of the paper is organized as follows: section 2 gives an overview on the Eurosystem's asset purchase programs and focus on the Public Sector Purchase Program (PSPP). Section 3 describes our data and details the methodology we use to extract PSPP expectations ; section 4 develops the tests and specifications of our models. Sections 5 and 6 deal with results and monetary policy implications. Section 7 concludes.

\section{The Eurosystem's Expanded Asset Purchase Program}

\subsection{Announcements and programs' parameters}

The Eurosystem announced on 22th January 2015 the expanded APP (Asset Purchase Program) ${ }^{7}$, to provide additional monetary policy stimulus to "help to bring inflation back to levels in line with the ECB's objective" and support credit conditions, "a precondition for inflation to return to and stabilise at levels close to $2 \%$ "

\footnotetext{
${ }^{7}$ Expanded APP merged the two existing asset purchase programs - CBPP3 on European covered bonds market and ABSPP on ABS market - with a new program on European sovereign bonds (PSPP). Details can be found in Annex and online here: https://www.ecb.europa.eu/mopo/implement/omt/html/index.en.html

${ }^{8}$ See https://www.ecb.europa.eu/explainers/tell-me-more/html/asset-purchase.en.html
} 
On top of existing purchases of covered bonds and asset-backed securities, the extended package included for the first time purchases of sovereign bonds from all jurisdictions ${ }^{9}$ under the PSPP program (Public sector purchase program). It was announced in a relative open-ended way, in terms of monthly purchase pace "until the Governing Council sees a sustained adjustment in the path of inflation" , rather than committing to a fixed size for the program. The Eurosystem's initial objective was to purchase 60 billion Eur ${ }^{10}$ of securities per month from 9th March 2015 and initially at least until September $2016^{11}$, all programs taken together. During the first year of implementation, this splits between an average 50 billion Eur per month for the PSPP and the remaining for the CBPP3/ABSPP.

PSPP purchases are then allocated between Euro area supranational issuers and between jurisdictions according to the national central banks (NCBs) shares in the capital of the ECB (the "capital key"). NCBs are generally in charge of purchasing the domestic debt(ie. Banque de France in charge of purchasing French bonds). Annex A details the major announcements.

Eligible bonds are Euro-denominated Euro area government nominal and inflation-linked bonds, maturing in at least 2 years and at most in 30 years, included ${ }^{12}$. Supranationals (EIB, EFSF...), agencies and parapublic corporates (CDC, SNCF Réseau...) are also admissible (Annex A details the list of eligible agencies for France $)^{13}$. Nominal bonds with a yield lower than the deposit facility rate $(-0.20 \%$, cut to $-0.30 \%$ on 3 rd Dec 2015 and $-0.40 \%$ on 10th March 2016) are not eligible. ${ }^{14}$

In addition, two limits are applicable to the Eurosystem's purchases: the "issue limit" sets maximum purchase of an individual bond to $25 \%$ of its outstanding (33\% since Sept 2015) and the "issuer limit" prevents the PSPP from purchasing more than one third of a country's total debt outstanding.

\subsection{On the concept of market neutrality}

The Eurosystem intends to conduct its interventions in the bond market "in a gradual and broad-based manner, aiming to achieve market neutrality in order to avoid interfering with the market price formation mechanism $^{15}$ ". The first practical illustration is that purchases, within each jurisdiction, are in principle allocated according to the maturity distribution, ie. proportional to existing outstandings ${ }^{16}$. It also implies that PSPP purchases would more or less replicate the average duration of the eligible debt outstanding, something that is verifiable in monthly data published by the ECB.

A second implication concerns transactions themselves, which should not create dislocation of the yield curve and impair market functioning, something that we will be able to test with our data. It also implies flexibility in the purchases of specific bonds, to preserve the liquidity and availability of bonds in special demand. These aspects were further clarified by ECB board member Benoit Coeuré ${ }^{17}$ : "One

\footnotetext{
${ }^{9}$ As of March 2016, the Eurosystem have not purchase any Greek bonds, though, as the country is still under EU-IMF plan.

${ }^{10}$ This was increased to 80 bn EUR the 10th March 2016, with the announcement of an extension of the purchases to European corporate debt (CSPP) - this is beyond the scope and the time period of our study.

${ }^{11}$ Subsequently postponed to March 2017 in December 2015, then to December 2017 in December 2016

${ }^{12}$ In December 2016, this was extended to 1 year of residual maturity

${ }^{13}$ From Dec 2015, the eligibility list has also been extended to local government debt

14 https://www.ecb.europa.eu/ecb/legal/pdf/oj_jol_2015_121_r_0007_en_txt.pdf. In December 2016, this rule ceased to apply, but this is beyond the scope of our study.

${ }_{15}$ Official statement: https://www.ecb.europa.eu/mopo/implement/omt/html/pspp.en.html

${ }^{16}$ https://www.ecb.europa.eu/mopo/implement/omt/html/pspp-qa.en.html "Purchases will in principle be weighted by nominal outstanding amounts, with eligible remaining maturities at the time of purchase ranging from 2 to 30 years, also taking into account the issue and issuer limits as well as potential distortions in certain maturity buckets"

17 "Embarking on public sector asset purchases" Speech by Benoit Coeuré, Member of the Executive Board of the ECB, at
} 
key principle underlying the implementation of the PSPP is [...] market neutrality of our operations. By this we do not imply that we do not want to have any impact on the market. [...] This should prevent significant dislocations along the yield curves and other similar undesirable market distortions. [...] Another important issue concerning the successful implementation of the PSPP is market liquidity. Currently, the market for euro area government debt constitutes one of the most liquid segments of global financial markets, and investors can transact large amounts of securities without moving market prices to a significant degree. [...] To this end, we will take particular care to avoid exacerbating any existing market frictions. More specifically, we will try to avoid, to the extent possible, purchasing specific securities such as current cheapest-to-deliver bonds underlying futures contracts, securities commanding special rates in the repo market as a sign of temporary scarcity, and other assets displaying significant liquidity shortages."

We derive from these guidelines some important implications that matters from the practical understanding of the purchases, as well as from the econometric point of view, both for the proper specification of the models, and the results we can expect. First, if purchases are made to minimize the market impact of transactions, the primary transmission of the purchases should not be observed through deformations of the yield curve ; at least they should remain temporary. Second, due to their specialness or liquidity conditions, some bonds might be relatively less purchased than others. Third, the strict observation of an exogenous rule for the purchases, based on capital key, nominal outstanding, at a fixed and predetermined pace, limits concerns about a possible endogeneity biais ${ }^{18}$ that would arise if on the contrary PSPP was set up to target rising yield bonds, for instance.

\section{Data}

We first detail the bond-level data used and describe our panel. Then we show how we constructed our proxy of expectations of total purchases.

\subsection{Bond-level data}

Bonds characteristics We recover data about all bonds alive from 01/01/2014 from French central government and public agencies, both ineligible and eligible to the PSPP. French public debt is the second largest Euro area government debt market, representing around $20 \%$ of the outstanding, and also the second most purchased market by the Eurosystem under the PSPP program, due to the application of the capital key. It is also one of the most representative in terms of variety of instruments (nominal, inflation-linked bonds...) maturities (with around 60 lines between the 1-year and the 50-year maturities) and issuer types (central government, public agencies...).

We recover bonds standard characteristics (nominal outstanding, maturity, convexity...) from Bloomberg for each individual security identified by its unique ISIN, and compare with external sources to ensure their consistency. For all these bonds, we recover clean price and compute holding period return in clean price too, for different horizons. We use preferably price and price variation as in D'Amico and King (2013). In

the Second International Conference on Sovereign Bond Markets, Frankfurt, 10 March 2015

${ }^{18}$ A point also made by Andrade et al. (2016) 
order to test and to control for any potential concentration of Eurosystem purchases on underpriced bonds, we also compute the deviation before the start of purchases from a Nelson-Siegel type of model.

PSPP purchases For PSPP purchases, we use internal proprietary data on daily transactions made on the French government and agencies debt by Banque de France market operations desk, from 9th March 2015 to 9th March 2016, at the security level. The information we have about the transactions are the date, the book value, the nominal amount and the price at which the transaction was settled. The same security might be purchased several times during a day, and we sum the transactions on each individual security on a daily basis.

We denote for each bond $i$ the nominal amount purchased on day $t$ by $Q_{0, i, t}$ (Zero subscript stands for the own purchase of the bond $i$, as later on, we will define purchase in a maturity or in a bucket). Similarly, we define $Q T O T_{0, i, t}$ as the nominal stock purchased of bond $i$ by the Eurosystem since the onset of the program in $t$. We then define two ratios, one for the purchase flow $q_{0, i, t}$ corresponding to the daily nominal sum of purchase for the bond $i$ at date $t$ scaled by its residual outstanding, net of past purchases defined by $O_{0, i, t}-Q T O T_{0, i, t}:$

$$
q_{0, i, t}=\frac{Q_{0, i, t}}{O_{0, i, t}-Q T O T_{0, i, t}}
$$

Similarly, we define the ratio of total stock purchased since the beginning of the program $q$ tot $_{0, i, t}$ as the cumulative purchases scaled by the nominal outstanding $O_{0, i, t}$ of each bond $i$ :

$$
\text { qtot }_{0, i, t}=\frac{\sum Q_{0, i, t 0, t}}{O_{0, i, t}}=\frac{Q T O T_{0, i, t}}{O_{0, i, t}}
$$

The average ticket $Q_{0, i, t}$ during the first year of purchase if around $25 \mathrm{mn}$ Eur, that compares with an average outstanding of government bonds of about 25 bn Eur, and a daily turnover reported by the French Treasury of about 10 bn Eur, based on primary dealers' activity. Average qtot $_{0, i, t}$ ratio was close to $7.5 \%$ after one year of purchases.

We also define the same ratio $q \operatorname{tot}_{m, i, t}$ for a given maturity $m$, and to account for the possibility that the denominator could eventually itself react to purchases (ie. Treasuries issuing more of a security through "taps" for instance), we also compute the same ratio on lagged outstanding, as of Dec 31st 2014.

Specialness and liquidity French government bonds are also among those most used in repurchase agreements (repo) and future contracts. We distinguish two types of specialness, according to the guidance provided by the speech of Benoit Coeuré:

- Cheapest-to-Deliver (CtD): As standardized and liquid products, future contracts on bonds are written on specific maturities (5-year, 10-year) and the underlying bond traded is a fictive bond, not a real one $^{19}$. In practice, the exchange where the contract is listed allows for delivery a basket of bonds whose maturities are close to the one of the fictive bond. As a result, a trader short in a future contract can choose for delivery any of them, at its discretion, if the delivery has to be made. There is one bond in the basket that offers the highest return when combined with the short position in the future contract. This bond is referred to as the "Cheapest-to-Deliver" (CtD).

\footnotetext{
${ }^{19}$ For instance, for a future contract on a 10-year sovereign French bond, the underlying asset of the contract exchanged in Eurex is a fictive $6 \% 10$-year term-to-maturity bond.
} 
- Repo special: a bond particularly in demand in the repo market ${ }^{20}$. In a repo transaction, the counterparty who lends cash against collateral may enter the trade in order to receive a specific security rather than a bond from the general collateral (GC), ie. the pool of securities admissible to secure the repo transaction. In that case, picking a specific bond as collateral generally reflects in a lower rate compared to the rate received in a transaction secured by GC (the "specialness premium"). Thus, we identify these repo special bonds by the spread between their reverse repo rate - the rate securities borrower accept to lend cash for having this security as collateral - and the GC repo rate.

On top of these specialness characteristics, we recover proxies for liquidity. We define characteristics such as a dummy for very small issuances (a proxy of relative scarcity, that we set at the lowest quartile for each issuer) and whether the bond is far off-the-run, which is associated with lower liquidity (Krishnamurthy, 2002). We also get from the French debt management office (Agence France Trésor - AFT) the stripping activity on the French sovereign debt, as it might affect the free float of each bond and be non neutral for some French government bonds.

\subsection{Panel stats}

Our dataset consists of 451 unique bonds, that we track from 01/01/2014 to 09/03/2016, issued in France by the government and by public agencies. All bonds are not alive in the sample during the whole period, notably because at this stage we have short term bonds that matured or bonds that were issued during the period. We dropped bonds for which we did not have at least both price and outstanding, so it might be the case that the nominal outstanding we have for each issuer is not the exact total amount issued.

Table 1: Panel data - descriptive stats, as of 9th March 2016, in bn Eur

\begin{tabular}{lrrrr}
\hline issuer & Nom. outstanding & No of ind. ISIN & No of elig. bonds & Nom. cum. PSPP \\
\hline AGFRNC (AFD) & 17 & 18 & 10 & \\
CADES & 160 & 27 & 14 & \\
CDCEPS (CDC) & 9 & 31 & 18 & \\
CNA & 4 & 3 & 2 & \\
GOV & 1272 & 55 & 34 & \\
OSEOFI (BPI) & 9 & 9 & 8 & \\
RESFER & 27 & 28 & 17 & \\
UNEDIC & 17 & 12 & 7 & 80 \\
\hline Total & 1513 & 183 & 110 & \\
\hline
\end{tabular}

Reported are the bond alive as of 9th March 2016, that were issued before Jan 2015 (in order to balance the panel) and for which we have at least price, outstanding, maturity and convexity data.

Cumulative PSPP purchases are indicative, they concern only this sample and might be slightly below the total purchases of French public debt.

Overall, for the French government debt, we match for instance $90 \%$ of the nominal outstanding as stated by the $\mathrm{AFT}^{21}$. Cleaning and balancing the panel restricts the sample to 183 bonds, among which 110 are eligible to the PSPP, as of 9th March 2016.

\footnotetext{
${ }^{20}$ This dimension is particularly explored for the US Treasury market by Duffie (1996) D'Amico et al. (2014) and Duffie and Krishnamurthy (2016)

${ }^{21}$ http://www.aft.gouv.fr/rubriques/encours-de-la-dette-negociable-de-l-etat_159_lng1.html
} 


\subsection{Extracting expectations of the total size of the central bank's purchases}

Expectations on the total size of the central bank's asset purchases are valuable to assess, on top to cumulative stock of purchases made and transactions themselves, the impact of time-varying expectations of future purchases. They constitute a third type of supply shock through which asset purchase program might be effective. Unfortunately, there is no direct measure available, and to our knowledge no regular poll conducted that would directly report these expectations. Still, what we do is to infer from other questions asked in polls an expected variation of the central bank balance sheet that we can attribute to asset purchases.

Ahead of each ECB Governing Council, Thomson Reuters conducts a poll of professional forecasters on their monetary policy expectations. From November 2014, Reuters also asked more precise questions about the probability the ECB would embark in an asset purchase program and particularly questions on the size of the ECB balance sheet at various horizons. Annex B details the poll data and methodology used. In a nutshell, we use the median of these expectations of balance sheet change $E_{t}\left(B S_{T}\right)$ to compute a proxy for the total size of the purchases at the end of the program $E_{t}\left(Q E T O T_{T}\right)$, at the final date $T$. In practice we set $\mathrm{T}$ as the longest forecast horizon (2017).

$$
E_{t}\left(Q E T O T_{T}\right)=\left[E_{t}\left(B S_{T}\right)-B S_{t}\right]+Q E T O T_{t}-E_{t}\left[\Delta_{t, T}(O T H)\right]
$$

where $B S_{t}$ stands for the size of the ECB balance sheet at the date $t, Q E T O T_{t}$ the total amount of purchase at date $t$ and $E_{t}\left[\Delta_{t, T}(O T H)\right]$ the expected variation of all elements in the balance sheet except those linked to QE. Among these "other items", there are conflicting forces: some are driving down the balance sheet - like reimbursements of previous liquidity-providing operations, or gradual maturing of SMP purchases - and some are driving up the balance sheet, such as expected take ups to new operations, like TLTROs. Evidence of the composition of ECB balance sheet since 2014 shows that these forces tends to cancel out, so that we can set $E_{t}\left[\Delta_{t, T}(O T H)\right] \approx 0$. Put differently, we assume that PSPP is the main driver of the variation in the expected size of the ECB balance sheet, something that is supported by the data, see Figure 7 .

We backtested our proxy with known official announcements on QE size by the Governing Council, and we find that it fits reasonably well (see Figure 2). Annex B shows our measure is also robust to variations induced by LTROs and T-LTROs expected by market participants, mainly because refinancing operations tend to substitute each other. To cross-cross check the inflexion observed between April and July 2015 in our measure, we used a different poll run by Bloomberg, on the tapering probability of Eurosystem's PSPP. Set at its inception to last 19 months, we show in Figure 8 that the distribution of early tapering of PSPP (ie. the PSPP won't last at full pace 19 months) shifted significantly with the same timing. Both reflect from April 2015 to the Summer 2015 a reduction in the expectations of growth of the ECB balance sheet and thus a reduction in the accommodative signals of the ECB policy. 
Figure 2: Balance sheet expansion proxy of QE-total size expectations, trillion Eur

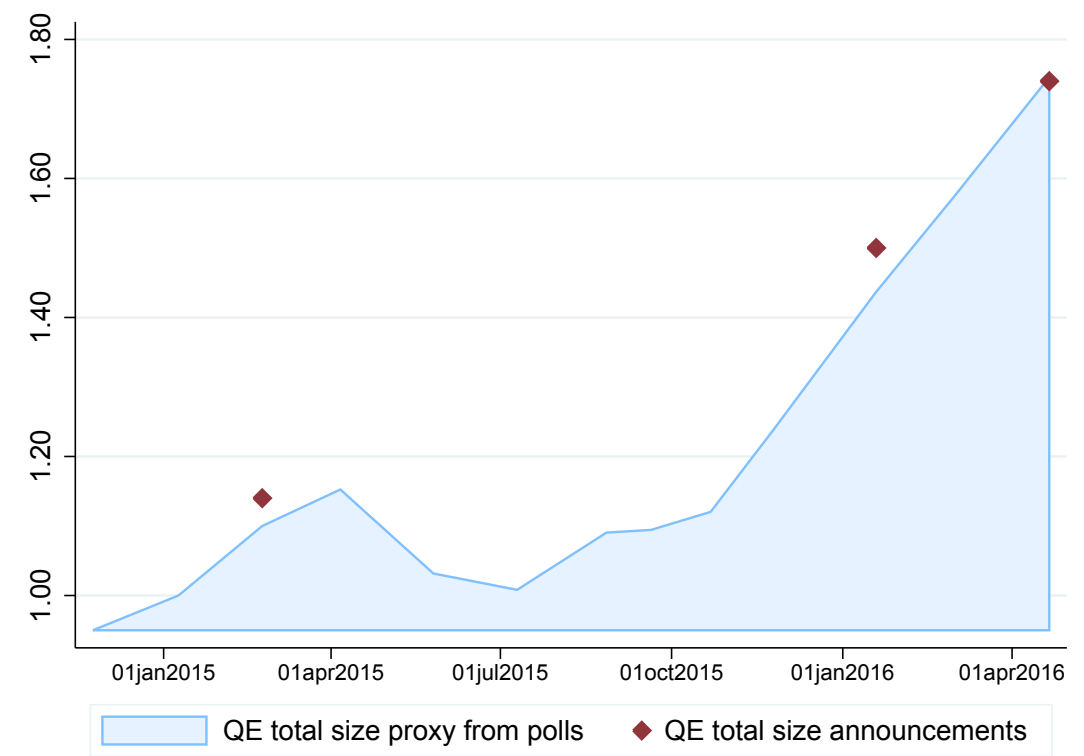

Note: The total size of QE proxy is computed from the median extracted from Reuters SPF polls according to our methodology. The QE total size announcements correspond to announcements or changes made by the ECB that implied a revised total size for the asset purchase programs: 22 Jan 15 (60 billion/month until Sept 2016) / 21 Jan 16 (60 billion/month until March 17) / 21 Apr 16 (80 billion/month until March 17)

\section{Methodology}

In this section, we first carefully define the three types of supply shocks behind asset purchases and make links with channels predicted by theory. Then we detail the specifications for each type of shock.

\subsection{Stock, flows, and expected stock}

In the following, we investigate three types of possible effects of asset purchases (stock, flow, and expected stock): (i) stock refers to (past) security-level cumulative purchases since the onset of the program (ii) flow refers to the price impact of each PSPP transaction at the security-level (iii) expected stock corresponds to the time-varying expectations of the total size of purchases between the start of the program and its expected end. By construction, in terms of amounts purchased, expected stock equals stock plus cumulative future flows, and stock equals the sum of past flows. But this accounting equation is not necessarily true for the price effects stemming from each of these types of supply shocks. A example is when the stock is perfectly anticipated and already priced in, for instance, which should imply no effect from flows.

For the stock and flow analysis, our method is similar to the security-level study of D'Amico and King (2013) in the US Treasuries bond market, and Joyce et al. (2010) in the UK Gilt market. Following their approach, we estimate the elasticity of bond price change to the central bank's purchases, both in cross section (related to the stock removed) and in panel (related to transactions themselves).

This is also an indirect test for transmission channels of QE predicted by the theoretical literature. In a 
Vayanos and Vila (2009) type of model, preferred habitat investors with preferences for certain bonds coexist with risk averse arbitrageurs. In their model, asset purchases affect price through two possible channels. The first one ("local supply" or scarcity channel) predicts that price impacts are specific to the securities purchased and persistent in presence of incomplete arbitrage activity. It corresponds to the intuition that purchasing a large share of $20 \mathrm{y}$ bond should primarily affects its own price, and possibly similar bonds. On the contrary, a second channel is at work in presence of complete arbitrage. In this case, purchasing a $20 \mathrm{y}$ bond does not show up in this particular bond price, but affects instead all bonds price through the whole term structure, as it reduces the overall quantity of duration risk borne by private markets. In our econometric setup, finding significant elasticity of purchases on return at the security-level, either on stock or on flows, would therefore support the existence of local supply effects.

\subsection{Stock effects specifications}

The stock specifications intend to capture the effects on bond prices of the total stock purchased by the Eurosystem, ie. the permanent impact of removing part of the supply of a bond through central bank asset purchase. We run it on the cross-section at date $t=9$ th Mar 2016, 1 year after the start of the purchases, and subsequently at different dates to see the dynamics of the elasticity $\beta$.

$$
R_{i}=\alpha+\beta q \text { tot }_{0, i}+\gamma X_{i}+\epsilon_{i}
$$

where $R_{i}$ is the clean price holding period return of bond $i$ since a reference date (we set it to 2nd Jan 2015, just before the announcement of the program) and 9th Mar 2016. $X$ is a set of controls: we include maturity (to capture moves common to a specific maturity, orthogonal to purchases) and convexity (what literature approximates generally with the squared maturity)

To account for the possibility that purchases in a maturity bucket might be the relevant measure (purchase of one bond in the 10y maturity might matter for all 10y bonds), we also run specification where $q t_{o t} t_{m, i}$ is the ratio of purchase in a maturity $m$ over the total outstanding of the same maturity.

$$
R_{i}=\alpha+\beta q \text { tot }_{m, i}+\gamma X_{i}+\epsilon_{i}
$$

These specifications can be estimated by OLS, or through a two-stage least square procedure, if we suspect an endogeneity biais ${ }^{22}$. In the case of PSPP, there are reasons to be less concerned about the endogeneity bias. The implementation did not respond to a rise in yield (See Andrade et al. (2016)), but rather to strict rules, based on steady purchases along the curve, split according to capital key and maturity distribution that can be assumed exogeneous (Koijen et al. (2016)). We give OLS results in the next section keeping in mind estimates might underestimate the elasticity $\beta$, and thus are likely to be a lower bound of purchases effects. As we explained, there are less concerns with the implementation of PSPP, but still we can control for the possibility that purchase quantities might have been affected by overpriced bonds generally signaling a bond in particular demand. Following indications on the purchase strategy given in the speech of Benoit Coeuré, we build an instrument from a set of variables that indicates different types of specialness

\footnotetext{
${ }^{22}$ The literature on asset purchases and notably on the SMP program (Doran et al. (2013), Ghysels et al. (2014) or Eser and Schwaab (2016)) highlights a risk of endogeneity if the NCBs targeted primarily bonds that were underpriced, possibly resulting in a spurious positive correlation between yields and purchases.
} 
and liquidity/scarcity for each bond as of March 2015, just before the start of the program:

- whether the bond was or would be the cheapest-to-deliver bond of future contracts within the period

- whether it was particularly in demand in the repo market as of March 2015

- to take into account liquidity, we set a dummy for each issuer, and control for bonds with a particularly small issuance volume, whether they are on-the-run or off-the-run, or affected by a strong stripping activity.

- we also take into account whether the issuer is the central government or an agency, and whether the bond is nominal or inflation-linked (which is supposed to be a less liquid market)

Hence, first stage is of the following form:

$$
\widehat{\text { qtot }_{0, i}}=[\beta(\text { specs })+\gamma(\text { liquidity })] \times \text { eligible }+\eta
$$

We interact the specialness and liquidity indicators with an eligibility dummy to let the first stage be different from zero only for bonds which have been at least once eligible to the program.

\subsection{Flows effects specifications}

In line with literature, we adopt a very restrictive measure for flows effects: the deviation from the average move in yields the same day, captured by the time fixed effect. In this setup, if a transaction is perfectly absorbed and yield curve arbitraged at the end of the day, no effect will be detectable from our data. A general caveat is thus that we observe purchases and price at a daily frequency and we mostly ignore intraday moves.

The baseline panel regression we run for flows (ie. daily effect of a daily purchase of the bond $i$ ) is:

$$
R_{i, t-1, t}=\alpha+\beta q_{0, i, t}+F E_{i}+F E_{t}+\epsilon_{i, t}
$$

where $R_{i, t-1, t}$ is a daily return, $F E_{i}$ is an ISIN-specific fixed effect aiming at capturing persistent patterns specific to a given security and $F E_{t}$ a time-fixed effect.

We also run the analogue of Eq 4, with purchase ratio over the maturity bucket $q_{m, i, t}$.

\section{4 "Expected stock" specifications and the scale-down hypothesis}

Finally, we test the scale-back hypothesis. If true, it means that besides purchases made in the past of a bond that changed its supply/demand equilibrium, bond prices also react to expected supply shock and to changes in these expectations.

First of all, looking back to our first Figure 1, a first test would be to see if - in aggregate and in time series for French 10y yield - whether a correlation holds between the moves in yields and the variations in expectations of total size of APP (Figure 2) that we recovered from polls.

We use time series data to estimate this correlation, but we need to control for possible confounding macroeconomic variables. As a first test, we run the following time series model: 


$$
\Delta Y_{10 y, t}=\alpha+\beta \Delta E_{t}(Q E T O T)+\gamma \Delta X_{t}+\epsilon_{t}
$$

Where $Y_{10 y, t}$ is now the 10 year generic yield-to-maturity, $E_{t}(Q E T O T)$ the proxy of total size of the program expected by market participants, and $X$ a set of controls. Notably, we control for macroeconomic sentiment indicator (ESI), the expectations of inflation derived from 10y inflation swap, and fiscal deficit next year.

Second, using our granular data, we can take advantage of the fact that changing expectations in the total size of the PSPP program are likely to have a differentiated impact according to the eligibility status of bonds (whether a bond is eligible to PSPP or not implies it is concerned or not about future purchases). Put differently, we expect that a downward revision in the total size of the PSPP had a significantly larger impact on those bonds that are directly concerned by the purchases of the Eurosystem.

We run a difference-in-difference panel regression between the start of the purchases and the end of the sell-off. We interact the eligibility dummy with a dummy taking the value 1 during the sell-off period.

$$
R_{i, t}=\alpha+\beta[\text { Eligible } \times \text { Selloff }]+\gamma X_{i, t}+F E_{i}+F E_{t}+\epsilon_{i, t}
$$

\section{Results}

What do we expect? Market neutrality described by Benoit Coeuré, if fully implemented, should lead to small results in flows, as market impact is explicitly said to be avoided. As we argued is previous section 4.1, this is without prejudice of finding stock effects. Regarding the sell-off period, we expect that a downward revision in the total size of the program would have an impact greater for eligible bonds that for ineligible bonds.

We run regressions in period returns. This is partly motivated by the data, as price was the most available and reliable valuation data in our sample, but also with concerns that low rates increased convexity of most bonds during this period implying that price changes are likely to be more significant than yield changes for these reasons. When we give results in bps, we translate period return results into yield results, using the following approximation ${ }^{23}$ and making some assumptions about duration $D$ and convexity $C$ :

$$
R_{i, t, t+1} \approx y_{i, t}-D * \Delta\left(y_{i, t, t+1}\right)+\frac{1}{2} C * \Delta\left(y_{i, t, t+1}^{2}\right)
$$

In the remainder, we will give results in yields for a representative 10y bond of 7 years of duration, at par, considering yield income and convexity term are negligible during the period.

\subsection{Stock effects}

First, we run the stock regressions (see Table 3), 12 months after the beginning of QE, with period return as the dependent variable, and the cumulated purchase ratio qtot $t_{0}$ at the right hand side. Overall, we find that $1 \%$ of outstanding purchased is associated to a drop of about -0.7 (column 2) /-1.3 bps (column 4) for

\footnotetext{
${ }^{23}$ See for instance Campbell, Lo and MacKinlay, "The Econometrics of financial markets", 1997, pp405-407 or Veronesi (Ed.), "Handbook of Fixed-Income Securities", 2016, p 121. D'Amico and King (2013) use the same approximation.
} 
a $7 \mathrm{y}$ duration $10 \mathrm{y}$ bond yield ${ }^{24}$ or -13 bps for $10 \%$ of outstanding purchased. This result holds with different types for bonds: all bonds, only eligible, and only purchased.

The effects (Table 4) seem greater for inflation-linked bonds (-2.4bps), and longer maturities bonds ($5.3 \mathrm{bps}$ ), consistent with lower liquidity and possible preferred habitat demand in these markets. This is also a prediction from theory, as purchasing the same amount of longer bonds remove more duration than purchasing the same amount in short term bonds. A caveat is the limited number of bonds we have to run regressions by bond type.

Table 5 shows the analogue regression of Table 3 , but split by time period subsets. The stock effect we found is significant through time, but also it seems to fade out in time ${ }^{25}$, possibly because adjustment to the new supply conditions may take time. It suggests - at least during this first year of implementation that the main driver of stock effect was rebalancing frictions, consistent with preferred habitat, rather than scarcity (scarcity would rather increase the elasticity of price impact of purchase). This diminishing elasticity is consistent, also, with the fact that effects arising from local supply dissipate as arbitrageurs integrate the different bond market segments, something that is predicted by Vayanos and Vila (2009) and which would take more time than we might thought.

Then we run 2SLS and report results in Table 6. Column 1 gives the results of the first stage, which has an adjusted $R^{2}$ of about $50 \%$. We "anonymized" liquidity and specialess indicators not to disclose too much information about the rules used by PSPP traders. First stage show that some specialness and liquidity indicators have been taken into account. There are drawbacks to the method, as we lose some of the bonds in our panel, mainly because for some agencies, it was not possible to construct a relative valuation measure.

Overall, the IV specifications reinforce our results. Magnitude of the results is bigger than OLS, with results ranging from -2.6 to a maximum of -8 bps per $\%$ of outstanding purchased (-26bps/-80bps for $10 \%$ of outstanding purchased). While longer maturities seem to have reacted more than short ones, the IV does not seem to suggest a large difference between ILBs and nominal bonds.

We run Sargan-Hansen test of the null hypothesis that the instruments used are valid, i.e. uncorrelated with the error term, and that they are correctly excluded from the estimated equation. In each specification, the p-value is above the usual confidence levels, suggesting that our instruments are valid ${ }^{26}$. Table 2 gives an overview of literature results. Stock effects range from -9 to -100 bps for the different asset purchase programmes in the US and in UK, from directly comparable methods (panel and cross section regressions ; we rescaled for purchases of $10 \%$ of outstanding). We also compared our results to other estimations available for PSPP with other data and other methodologies. Andrade et al. (2016) estimate the impact of announcement and first dates of implementation of the programme, Koijen et al. (2016) use the predicted split of the announced programme between countries and maturity buckets. In both cases, estimates come reasonably close to our -26bps IV result.

Robustness checks with lagged outstanding (of end 2014, before PSPP starts) give similar results both with OLS and IV estimation.

\footnotetext{
${ }^{24}$ Column 4 : coefficient 0.093 is in price return, we apply Eq 10. The approximation in bps is $0.093 / 7$ for a bond of $7 \mathrm{y}$ of duration.

${ }^{25}$ Other evidence of these "diminishing returns of QE" exist for other central banks asset purchase programs. See for instance Charles A. E. Goodhart \& Jonathan P. Ashworth, 2012. "QE: a successful start may be running into diminishing returns," Oxford Review of Economic Policy, Oxford University Press, vol. 28(4)

${ }^{26}$ We used the Stata routine ivreg2, and the tests as described in Baum, Scheffer, Stillman "Enhanced routines for instrumental variables/GMM estimation and testing", 2007
} 


\subsection{Flows effects}

Second, we run several flows regressions (Table 7, 8), with security and time fixed effects, to capture persistent patterns linked to a specific bond, as well as general movement of the yield curve in a particular day.

Coefficient of own purchase came insignificant in all specifications, as well as purchase within a maturity bucket. We run alternative specifications with cumulative purchase over the past 5 days to account for possible lags, focusing on large purchase tickets (95\% percentile), returns over a 2-day window, breakdown by bond type, with insignificant results as well.

The only effects we find is on the first day of purchase, associated with a small, barely significant (at $85 \%$ of confidence) effect. This presumably lies in the learning by market makers of the implementation framework of the PSPP. Having learned those features, that could have been different from their expectations, they could have adjusted afterwards.

We don't have intraday data to account for the possibility that price impact might be inobservable with end-of-day data. But we have the transaction price, which we use to compute a "maximum daily return" (return between previous day close price and the maximum price paid in PSPP transaction for a bond). This specification gives us a sense - for lack of anything better - of possible transitory, intra-day price impact. It's only when we restrict the sample to heavily purchased securities (holding by the Eurosystem higher than $25 \%$ ) that we find a small, significant price impact, suggesting that purchasing $1 \%$ of security outstanding would correlate with a transitory price impact of $-0.3 \mathrm{bps}$.

How do we compare with the literature with flows effects?

Table 2: Results from literature on central banks purchase programs

\begin{tabular}{|c|c|c|}
\hline Authors & Prog. & $\begin{array}{l}\text { Results (Stock effects rescaled for } 10 \% \text { of outstanding pur- } \\
\text { chased) }\end{array}$ \\
\hline D'Amico and King (2013) & US LSAP1 & $\begin{array}{l}\text { Stock effects: }-100 \text { bps } \\
\text { Flow: }-3.5 \text { bps }\end{array}$ \\
\hline Meaning and Zhu (2011) & US LSAP1\&2 & $\begin{array}{l}\text { Stock effects: }-32 \text { bps } \\
\text { Flow: }-3.5 \text { bps (LSAP1) }-4.7 \text { bps (LSAP2) }\end{array}$ \\
\hline Meaning and Zhu (2011) & UK APF & $\begin{array}{l}\text { Stock effects: }-9.3 \text { bps } \\
\text { Flow: }-1.5 \text { bps }\end{array}$ \\
\hline Joyce et al. (2010) & UK APF & $\begin{array}{l}\text { Stock effects: }-40 \text { bps } \\
\text { Flow: }-2.5 \text { bps }\end{array}$ \\
\hline Andrade et al. (2016) & PSPP & $\begin{array}{l}\text { Flow: no significant effect } \\
\text { Stock (event study on announcement and implementation } \\
\text { dates) }-27 \mathrm{bps}\end{array}$ \\
\hline Koijen et al. (2016) & PSPP & $\begin{array}{l}\text { Stock (estimated on country-level purchases predicted by } \\
\text { capital key): -35bps }\end{array}$ \\
\hline Arrata and Nguyen & PSPP FR & $\begin{array}{l}\text { Stock effects: }-13 \text { bps (average, OLS) }-26 \text { bps (IV) } \\
\text { Flow effects: mostly inexistant }\end{array}$ \\
\hline
\end{tabular}

We report the average effect of our results in OLS and IV for purchased bonds.For Andrade et al. (2016), we cite the result obtained in an event study. Euro area total government debt is approximately 11 trillion Eur, and at inception PSPP size was approximately 1,1 trillion, and thus approx. $10 \%$ of outstanding.

The quasi-absence of flow effects the day of purchase is striking compared to results from other QE programs, but not surprising given the implementation rules of PSPP and the market neutrality strategy described in section 2.2. This is in line, too, with findings of Andrade et al. (2016) and Koijen et al. (2016), 
who conclude with other methodologies that actual implementation of purchases led to barely nonexistent price effects in the Euro Area. Our own result suggests that flows effects are extremely difficult to detect, and are probably measurable only in very specific conditions.

\section{$5.3 \quad$ Expected stock effects}

Plotting our first graph (10-year yield) together with our measure of expected total size of APP suggests a clear negative relationship (Figure 3). We extended the data to sept 2016 and plan to update the series in future versions of the paper.

Figure 3: French generic 10y yield and expected total size of APP

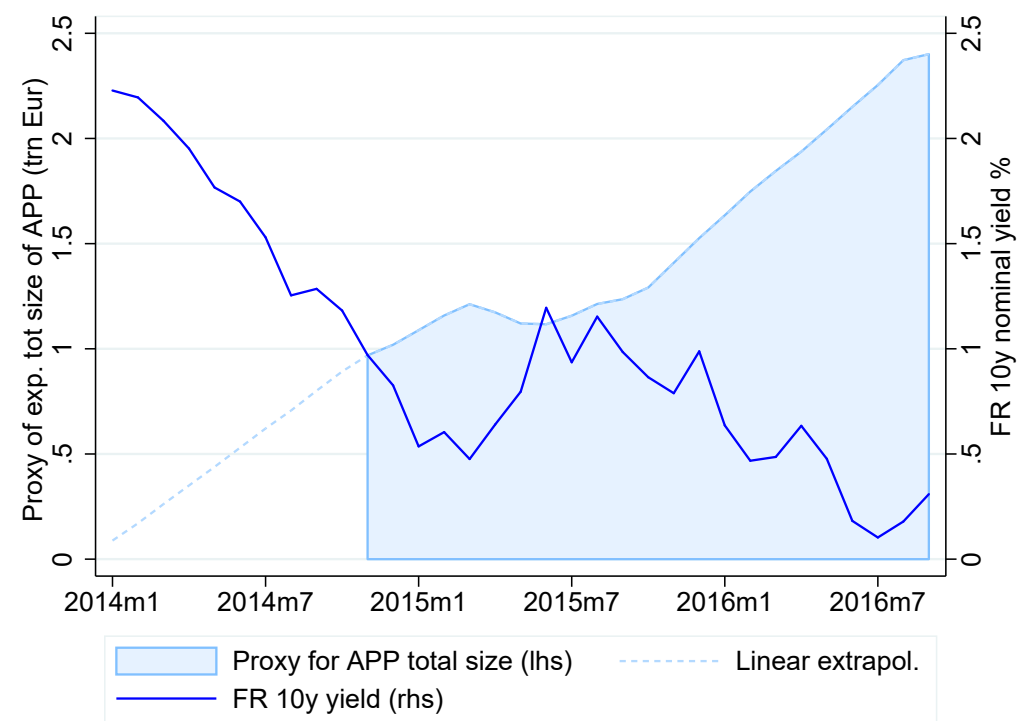

Note: Dashed line is "extrapolated" between Jan 2014 and Nov 2014, we simply traced what would have been visually the constant progression of expectations if they had been at zero in Jan 2014. Regression is run only on the actual series.

The relationship could stem from a confounding variable, ie. improvement of market sentiment explaining both rising yields and a reduction in expectations of purchases from the central bank. To control for this, we run regression 8. Results in table 9 show that even after controlling for macroeconomic conditions (captured by the Economic Sentiment Index, ESI), variations in expected inflation and variations in expectations of fiscal deficit ${ }^{27}$, our measure still correlates significantly with yields.

Second, as a first visual test with our panel, we plot bond returns by eligibility status in Figure 4.

Figure 4 suggests that non-eligible bonds made less gains than eligible bonds before the sell off, and they also less sold-off than eligible and purchased bonds. Put differently, we show there was a slight premium between eligibility status, that seems to invert during the sell-off. This is precisely what we should see as a downward revision of the total size of the program is likely to affect more eligible bonds (ie. the

\footnotetext{
${ }^{27}$ Over the period, French fiscal deficit is very stable, according both to quarterly projections of the Treasury and even slightly decreasing according to monthly-frequency poll of economists surveyed by Bloomberg.
} 
Figure 4: Bond returns by eligibility status before and during the sell-off

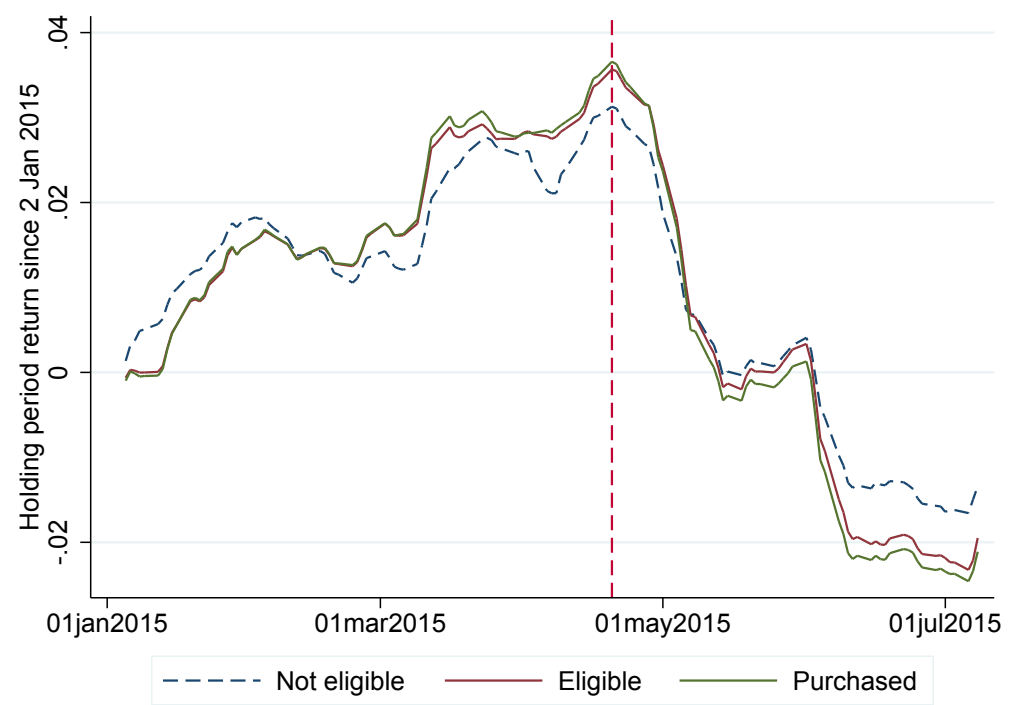

We compute holding period returns from 2nd Jan 2015 for three categories of French bonds: those beeing not eligible to PSPP, those eligible, and those eligible and already purchased - at least once. We show the 5-day moving average. Vertical dashed line corresponds to the start of the sell-off on 20th April 2015.

only concerned by the total size of purchases). Of course, these bonds share different characteristics, that command their eligibility status. We run regressions in controlling bond characteristics to see whether this difference still holds. Our diff-in-diff setup (Table 10) confirms that in every specification, non-eligible bonds were less sold-off than eligible and purchased bonds during the sell-off. Interestingly, eligibility seems actually associated with over-performance before the sell-off.

With a different approach focused on the security-level ownership concentration, Boermans et al. (2016) show that the more illiquid a bond is - according to their metrics - the more price shock was aggravated during the European sell-off. Our findings might be related if we consider that the Eurosystem ownership concentration contributed to reduce the free float of purchased bonds.

\section{Monetary policy implications}

\subsection{Does the implementation strategy of the purchases play a role ? A cross- country comparison}

Our results suggest that PSPP purchases are made in such a way that they are sufficiently split along the curve to avoid market impact. Figure 6 shows a boxplot of the daily maturity range of purchases by the Eurosystem, the Fed (QE2, MEP and QE3) and the BoE (APF). We define this maturity range as the maximum maturity minus the minimum maturity purchased within a day. This gives us an idea of the concentration vs the dispersion of the purchases along the yield curve. While Fed and BoE seemed to favor concentrated purchases, the Eurosystem median range was around 27 years on the French government debt, 
suggesting purchases occurred along the whole eligible yield curve (2-30y maturities, both included).

Regarding the purchase strategy, Eurosystem used preferably - for sovereign and agencies bonds - trading platforms or purchased on axes in bilateral transactions instead of running auctions ${ }^{28}$. This strategy is likely to have favored a smooth implementation of daily purchases. We showed also that purchases were split along the yield curve and tickets remained relatively small compared to daily turnover.

At the opposite, Fed (D'Amico and King, 2013) and BoE (Joyce and Tong, 2012) favored auctions, with pre-announcement of the securities to be purchased, generally a maturity bucket ${ }^{29}$. Figure 5 compares the distribution of the $q_{t o t, 0}$ ratio between the Fed, the BoE and the Eurosystem. What is striking is the specificity of Eurosystem, who paid a great attention to purchase a very similar proportion of each bond. At the opposite, the BoE and especially the Fed purchased from zero to their issue limit $(70 \%)$ in a more dispersed way.

\subsection{Reconciling and interpreting our results with theory}

Our interpretation of the results is the following. At the time of implementation of PSPP in Euro area, financial stress was low and thus risk aversion alone is unlikely to have prevented arbitrage activity. Still, we do find local supply effects - that are specifically attached to bonds purchased - showing up in positive elasticity between purchases and return. When we look at this elasticity through time, we observe a declining coefficient. This suggests that the variance in the distribution of purchases, which we use to identify the stock effect, gradually counts for less to explain the cross section of bond returns. This is actually consistent with a gradual rebalancing or arbitrage that might take place at a slower pace than we might thought. In Koijen et al. (2016), we measured the asset reallocation between asset classes by investors in the Euro area and assess the rebalancing channel in response to PSPP. We documented that set aside foreign investors, most investors seem to have a considerable inertia in their asset reallocation. The two channels (local supply vs duration risk channel) predicted by Vayanos and Vila (2009) type of models might indeed coexist rather than exclude each other (a point made in the US by Cahill et al. (2013)), with the former partially preceding the latter. Further investigation as the purchase program continues might show that bond scarcity resurrects local supply as well, and we leave this for further research.

Our experiments around the variation of the overall expected stock of the program suggests expected stock also plays an important role in price determination, as it seems to impact primarily eligible bonds. This is again quite intuitive in this type of setup, and rather consistent with the duration channel. With the set of rules given by the Eurosystem and distribution of purchases proportionally to the maturity distribution, it is easy to infer the future duration risk that will be removed from the market from the expectation about the total nominal size of the program. This is consistent also with the steepening of the yield curve that occurred during the European sell-off.

The absence of effects stemming from PSPP transactions themselves support the view that they are (i) too small compared to market turnover (ii) sufficiently split along the yield curve to minimize any local

\footnotetext{
${ }^{28}$ Trial reverse auctions were conducted for supranational bonds https://www.banque-france.fr/sites/default/files/ media/2016/12/20/continuation-of-reverse-auctions-under-the-pspp-after-the-test-period.pdf

${ }^{29}$ For the BoE: "The size of each weeks auctions and the gilts being purchased were announced at 4 pm on the Thursday of the week before each auction. The Bank made few changes to the timing and sizes of auctions for each maturity range of gilts, so auction participants could know with a fair degree of certainty which gilts the Bank would be purchasing weeks ahead of each Thursday announcement" (Joyce and Tong (2012))
} 
deformation (iii) well arbitraged at such daily frequency. Again, this result seems strong for the first year of purchases, but this would need to be confirmed as the program continues. In particular, scarcity effects could arise too at this frequency. It might be the case, too, that the more purchased bonds in the past are expected to be the more purchased in the future, and then that markets make projections on intermediate distribution of purchases (without surprise on transactions) and on the final $q t_{0, t} t_{0, T}$ ratio. This would be another way to generate stock effects without flows effects consistently with our result, but this would assume that markets are able to guess (as it is non public) qtot $_{0, i, t}$ through time, which might be a bit unrealistic. We leave for further research possible tests of this hypothesis.

\subsection{Odyssean vs Delphic forms of asset purchases}

The importance of expected stock suggests also that asset purchases work through convincing markets sometimes before the actual purchases of the central bank - that gains can be made in being long of the same assets than the central bank. Some of market players (arbitrageurs in Vayanos and Vila (2009) framework) can play strategically this kind of carry trade but might seek the slightest signal to reverse their trade and to short the central bank position (ie. selling bonds), as it was observed also for tapering rumors in the US in 2013 .

In a first phase of building expectations they might actually reinforce the effect of expected stock, acting like having temporary "preferred habitat" for the expected bonds to be purchased. But in a second phase, as expected stock stabilizes or is scaled down, these market participants unwind their positions. Combined with market micro-structure issues such as thin liquidity, and extreme positioning, as it is the case for bond market in times of QE, this might catalyze such kind of sell-off and large repricing. This type of mechanism relying on the building and the potential reversal of carry trade is generalized for instance in Acharya and Plantin (2017), who highlight as well the adverse consequence it might have on financial stability.

Our results suggest that building gradual expectations over the total size of a QE program is crucial as long as the central bank needs to keep rate level and volatility low for this kind of reasons. It advocates clarity over the type of commitment, whether it's revisable and data-dependent("Delphic") or fixed and intangible ("Odyssean"). As prices partly react contemporaneously to expected total size of asset purchases, this seems to be key to avoid uncontrolled, untimely rise in yields.

\section{Conclusion}

In this paper, we use security-level data to measure the effect of the first 12 months of purchase of the PSPP on bond returns. Our results are threefold.

First, they suggest that during this period, purchasing around $10 \%$ of the outstanding would lower yields by -13 with a maximum effect of -53 bps for longer maturities. A second estimation method by instrumental variable, correcting for possible endogeneity bias in the OLS, confirms this result, and gives stronger coefficients, about -26 bps per $10 \%$ purchased on average and a maximum effect on longer maturities (-80bps).

Second, set aside very specific conditions (first day of purchase, transitory effects on bonds already heavily purchased), actual transactions did not show supplemental significant effects on the day of purchase, possibly because we are still at the beginning of the program, with purchases still moderate compared to outstanding. 
This is not surprising given the specificities in the implementation of the program and is in line with market neutrality.

Third, regarding the sell-off period, the reduction of the total size of PSPP expected by market participants seem to have played a role, but cannot explain the magnitude of the sell-off by itself. Presumably, it added to other factors which made believe market participants that gains from QE were already made.

We provide some new analysis of the differences in implementation and purchase strategies among central banks, possibly related to the differences observed in terms of price impact. 


\section{Regressions results tables}

Table 3: Cross-section OLS on 9 Mar 2016

Dependent variable: security-level period return since 2 Jan 2015

Coefficient of qtot $t_{0}$ (stock of own purchase scaled by outstanding) suggests that on average, purchasing $1 \%$ of a bond is correlated with a positive return of between 0.05 and $0.09 \%$ on this period. This translates into a drop of $-0.7 /-1.3$ bps in yields for a representative 10-year bond of 7-year duration (See Eq 10)

The last specification replaces $q$ tot $_{0}$ by the same ratio, but within a maturity (how much of outstanding has been purchased in a given maturity) and gives similar results.

\begin{tabular}{|c|c|c|c|c|c|}
\hline & $\begin{array}{c}(1) \\
\text { Baseline }\end{array}$ & $\begin{array}{l}\text { (2) } \\
\text { Mat controls }\end{array}$ & $\begin{array}{c}(3) \\
\text { Elig only }\end{array}$ & $\begin{array}{c}(4) \\
\text { Purch only }\end{array}$ & $\begin{array}{c}(5) \\
\text { Same mat }\end{array}$ \\
\hline q0_tot & $\begin{array}{c}0.0115 \\
(0.0257)\end{array}$ & $\begin{array}{l}0.0478^{* *} \\
(0.0203)\end{array}$ & $\begin{array}{l}0.0530^{* *} \\
(0.0247)\end{array}$ & $\begin{array}{c}0.0930^{* * *} \\
(0.0224)\end{array}$ & \\
\hline eligible & $\begin{array}{l}0.0145^{* * *} \\
(0.00383)\end{array}$ & $\begin{array}{l}0.0115^{* * *} \\
(0.00333)\end{array}$ & & & \\
\hline maturity & & $\begin{array}{c}0.00102^{* *} \\
(0.000477)\end{array}$ & $\begin{array}{c}0.000418 \\
(0.000681)\end{array}$ & $\begin{array}{l}0.00182^{* * *} \\
(0.000624)\end{array}$ & $\begin{array}{c}0.00175^{* * *} \\
(0.000653)\end{array}$ \\
\hline convexity & & $\begin{array}{c}0.00204 \\
(0.00292)\end{array}$ & $\begin{array}{c}0.0102^{* *} \\
(0.00416)\end{array}$ & $\begin{array}{c}0.00302 \\
(0.00354)\end{array}$ & $\begin{array}{c}0.00339 \\
(0.00364)\end{array}$ \\
\hline qtot_mat & & & & & $\begin{array}{l}0.0720^{* *} \\
(0.0280)\end{array}$ \\
\hline Adjusted $R^{2}$ & 0.076 & 0.369 & 0.482 & 0.515 & 0.478 \\
\hline Observations & 187 & 183 & 110 & 97 & 97 \\
\hline
\end{tabular}


Table 4: Cross-section OLS on 9 Mar 2016, by issuer and bond type

Dependent variable: security-level period return since 2 Jan 2015

We run the same stock regression but on subsamples by issuer (agencies or government) and type of bond. Nominal bonds contains all nominal bonds issued by agencies and government and ILB contain all indexedlinked bonds. Results range from -0.7 (agencies) to -5.3 bps (long term bonds) per percent outstanding purchased

\begin{tabular}{|c|c|c|c|c|c|}
\hline & $\begin{array}{c}\text { (1) } \\
\text { Agencies }\end{array}$ & $\begin{array}{c}(2) \\
\text { Gov } 2-10 y\end{array}$ & $\begin{array}{c}(3) \\
\text { Gov }>10\end{array}$ & $\begin{array}{c}(4) \\
\text { Nominal }\end{array}$ & $\begin{array}{l}(5) \\
\text { ILB }\end{array}$ \\
\hline q0_tot & $\begin{array}{c}0.0553^{* * * *} \\
(0.0190)\end{array}$ & $\begin{array}{c}0.267^{* * *} \\
(0.109)\end{array}$ & $\begin{array}{c}0.366^{* * * *} \\
(0.0744)\end{array}$ & $\begin{array}{c}0.0782^{* * * *} \\
(0.0196)\end{array}$ & $\begin{array}{l}0.167^{* *} \\
(0.0795)\end{array}$ \\
\hline maturity & $\begin{array}{l}0.00110^{* * *} \\
(0.000504)\end{array}$ & $\begin{array}{c}0.00109 \\
(0.00198)\end{array}$ & $\begin{array}{l}-0.000483 \\
(0.000696)\end{array}$ & $\begin{array}{c}0.00130^{* * * *} \\
(0.000476)\end{array}$ & $\begin{array}{c}-0.000755 \\
(0.000821)\end{array}$ \\
\hline convexity & $\begin{array}{c}0.00105 \\
(0.00360)\end{array}$ & $\begin{array}{l}0.0148^{* * *} \\
(0.00537)\end{array}$ & $\begin{array}{c}0.00789^{* * *} \\
(0.00306)\end{array}$ & $\begin{array}{l}0.000800 \\
(0.00309)\end{array}$ & $\begin{array}{c}0.00860^{* * *} \\
(0.00370)\end{array}$ \\
\hline Adjusted $R^{2}$ & 0.256 & 0.346 & 0.776 & 0.330 & 0.697 \\
\hline Observations & 128 & 29 & 16 & 167 & 16 \\
\hline
\end{tabular}

Table 5: Cross-section OLS - X months after the beginning of the purchases

Dependent variable: security-level period return since 2 Jan 2015

We run the same stock regression but on different time periods: 3, 6, 9 and 12 months after the beginning of the purchases. Results suggest that the stock effects we found in the previous tables faded out in time, from $-2.7 \mathrm{bps}$ per percent outstanding purchased the first 3 months of implementation to $-0.7 \mathrm{bps}$ over one year

\begin{tabular}{lcccc}
\hline \hline & $(1)$ & $(2)$ & $(3)$ & $(4)$ \\
& 3months & 6months & 9 months & 12 months \\
\hline q0_tot & $0.192^{* * *}$ & $0.0707^{* * *}$ & $0.0639^{* * *}$ & $0.0478^{* *}$ \\
& $(0.0690)$ & $(0.0232)$ & $(0.0198)$ & $(0.0203)$ \\
maturity & -0.000263 & 0.000536 & 0.000609 & $0.00102^{* *}$ \\
& $(0.000438)$ & $(0.000354)$ & $(0.000439)$ & $(0.000477)$ \\
convexity & $-0.00775^{* * *}$ & $-0.00759^{* * *}$ & $-0.00499^{*}$ & 0.00204 \\
& $(0.00241)$ & $(0.00215)$ & $(0.00263)$ & $(0.00292)$ \\
eligible & $-0.0108^{* * *}$ & $-0.0101^{* * *}$ & -0.000379 & $0.0115^{* * *}$ \\
& $(0.00273)$ & $(0.00238)$ & $(0.00306)$ & $(0.00333)$ \\
\hline Adjusted $R^{2}$ & 0.475 & 0.370 & 0.080 & 0.369 \\
Observations & 207 & 199 & 188 & 183 \\
\hline \hline
\end{tabular}

Standard errors in parentheses

Dependent variable: Holding period return since Jan 2015

${ }^{*} p<0.10,{ }^{* *} p<0.05,{ }^{* * *} p<0.01$ 
Table 6: Cross-section IV on 9 Mar 2016

We show first stage and IV. We "anonymized" the spec and liquidity variables in the first stage not to disclose too much information about the rules used by PSPP traders. Sargan-Hansen test of over-identification is reported at the end of the table. As we used a large number of instruments we just modified the sample of bonds in specification (5) and (6) as we would have lacked observation to run the last one. One percent of outstanding purchased is correlated with an overall effect for eligible bonds (Column 2) of $0.00187 \%$ or approximately $-2.6 \mathrm{bps}$ for a 7 -year duration bond. Largest effect is found for longer maturities (6) of about -8bps.

\begin{tabular}{|c|c|c|c|c|c|c|}
\hline & $\begin{array}{c}(1) \\
\text { First stage }\end{array}$ & $\begin{array}{c}(2) \\
\text { Elig only }\end{array}$ & $\begin{array}{c}(3) \\
\text { Nominal }\end{array}$ & $\begin{array}{c}(4) \\
\text { ILB }\end{array}$ & $\begin{array}{c}(5) \\
\text { Gov } 2-10 y\end{array}$ & $\begin{array}{c}(6) \\
\text { Gov }>10\end{array}$ \\
\hline I_valuation & $\begin{array}{c}0.000273 \\
(0.000294)\end{array}$ & & & & & \\
\hline I_spec1 & $\begin{array}{c}-0.0362^{* * *} \\
(0.0118)\end{array}$ & & & & & \\
\hline I_liq1 & $\begin{array}{l}0.0137^{* * *} \\
(0.00440)\end{array}$ & & & & & \\
\hline I_spec2 & $\begin{array}{c}0.00177 \\
(0.0103)\end{array}$ & & & & & \\
\hline I_liq2 & $\begin{array}{l}0.00575 \\
(0.0168)\end{array}$ & & & & & \\
\hline I_liq3 & $\begin{array}{c}-0.0200 \\
(0.0140)\end{array}$ & & & & & \\
\hline I_liq4 & $\begin{array}{c}-0.0319^{+} \\
(0.0216)\end{array}$ & & & & & \\
\hline I_liq5 & $\begin{array}{c}0.0330^{*} \\
(0.0171)\end{array}$ & & & & & \\
\hline I_liq6 & $\begin{array}{c}-0.0416^{* * *} \\
(0.0124)\end{array}$ & & & & & \\
\hline maturity & $\begin{array}{c}-0.00135 \\
(0.00266)\end{array}$ & $\begin{array}{c}0.000220 \\
(0.00106)\end{array}$ & $\begin{array}{c}0.0000108 \\
(0.00205)\end{array}$ & $\begin{array}{c}-0.00000374 \\
(0.000770)\end{array}$ & $\begin{array}{c}0.00650 \\
(0.00494)\end{array}$ & $\begin{array}{l}-0.00121 \\
(0.00151)\end{array}$ \\
\hline convexity & $\begin{array}{c}-0.00209 \\
(0.0126)\end{array}$ & $\begin{array}{c}0.0111^{*} \\
(0.00671)\end{array}$ & $\begin{array}{c}0.0135 \\
(0.0125)\end{array}$ & $\begin{array}{l}0.00555^{+} \\
(0.00358)\end{array}$ & $\begin{array}{c}0 \\
(.)\end{array}$ & $\begin{array}{l}0.0140^{* *} \\
(0.00657)\end{array}$ \\
\hline q0_tot & & $\begin{array}{l}0.187^{* *} \\
(0.0852)\end{array}$ & $\begin{array}{l}0.186^{* *} \\
(0.0812)\end{array}$ & $\begin{array}{c}0.193^{* *} \\
(0.0914)\end{array}$ & $\begin{array}{l}0.477^{* * *} \\
(0.0973)\end{array}$ & $\begin{array}{l}0.553^{* * *} \\
(0.0841)\end{array}$ \\
\hline Hansen J stat P-val & & 0.2266 & 0.3401 & 0.2846 & 0.0701 & 0.7505 \\
\hline Adjusted $R^{2}$ & 0.531 & 0.361 & 0.381 & 0.721 & 0.555 & 0.664 \\
\hline Observations & 85 & 79 & 68 & 14 & 11 & 20 \\
\hline
\end{tabular}

Standard errors in parentheses

$+p<0.15,{ }^{*} p<0.10,{ }^{* *} p<0.05,{ }^{* * *} p<0.01$

A drawback our our instrument is that we cannot keep bonds for which we do not have relative valuation measure, typically for some agencies for which it was not possible to compute a NSS-type of measure. This explains why eligible bonds number drops to 79 .

Kleibergen-Paap test of weak instrument showed $\mathrm{F}$ statistics between 2.5 and 5 for the three first specifications second stages but the two last ones which had F statistics higher than 10. 
Table 7: Panel regression, isin and time FE, eligible bonds only

Dependent variable is daily return, except for (4) where it it a 2-day return, and (7) and (8) for which we use the maximum return between precedent day close and the maximum deal price paid in PSPP transactions. All specifications are insignificant but the last one, suggesting that a transitory local supply effect does exist for bonds for which PSPP already detains $15 \%$ of the outstanding, or more. The same regression with daily return as the dependent variable comes insignificant, suggesting that this effect is only transitory and does not persist until the end of the day.

\begin{tabular}{|c|c|c|c|c|c|c|c|c|}
\hline & $\begin{array}{c}(1) \\
\text { Own purchase }\end{array}$ & $\begin{array}{c}(2) \\
\text { Own purch. sq }\end{array}$ & $\begin{array}{c}(3) \\
\text { 5d purchase }\end{array}$ & $\begin{array}{l}(4) \\
2 d \text { return }\end{array}$ & $\begin{array}{c}(5) \\
\text { Same mat }\end{array}$ & $\begin{array}{c}(6) \\
\mathrm{q} 0 \stackrel{0.01}{>}\end{array}$ & $\begin{array}{c}(7) \\
\text { Max return }\end{array}$ & $\begin{array}{c}(8) \\
\text { q0tot }>0.15\end{array}$ \\
\hline q0 & $\begin{array}{c}-0.00233 \\
(0.00681)\end{array}$ & $\begin{array}{l}-0.00243 \\
(0.00715)\end{array}$ & & & & $\begin{array}{c}0.0301 \\
(0.0355)\end{array}$ & $\begin{array}{c}-0.00394 \\
(0.00705)\end{array}$ & $\begin{array}{l}0.0239^{* * *} \\
(0.00673)\end{array}$ \\
\hline q0_sq & & $\begin{array}{r}-0.00633 \\
(0.0315)\end{array}$ & & & & & & \\
\hline q0_5d & & & $\begin{array}{c}0.0000144 \\
(0.00149)\end{array}$ & $\begin{array}{l}-0.00205 \\
(0.00282)\end{array}$ & & & & \\
\hline q0_mat & & & & & $\begin{array}{l}-0.00277 \\
(0.00440)\end{array}$ & & & \\
\hline Time-FE & No & Yes & Yes & Yes & Yes & Yes & Yes & Yes \\
\hline ISIN-FE & No & Yes & Yes & Yes & Yes & Yes & Yes & Yes \\
\hline $\mathrm{N}$ & 35621 & 35621 & 35097 & 35097 & 35621 & 188 & 4204 & 75 \\
\hline
\end{tabular}

Standard errors in parentheses

Panel regressions on eligible bonds, from 09 Mar 2015 to 09 Mar 2016

$+p<0.15,{ }^{*} p<0.10,{ }^{* *} p<0.05,{ }^{* * *} p<0.01$

Table 8: Regressions on specific time periods

Specification (1) investigates the impact of the first day of purchase, we run it in the cross section, and control for maturity and convexity to capture common movement of the yield curve. All other specifications are panel regressions with security and time FE, they all suggest the absence of flow effects beyond the first day of purchases. The mean of $q_{0}$ the first day of purchase was 0.00254 .

\begin{tabular}{|c|c|c|c|c|c|c|}
\hline & $\begin{array}{c}(1) \\
\text { First day }\end{array}$ & $\begin{array}{c}(2) \\
\text { First week }\end{array}$ & $\begin{array}{c}(3) \\
\text { 3months }\end{array}$ & $\begin{array}{c}(4) \\
\text { 6months }\end{array}$ & $\begin{array}{c}(5) \\
\text { 9months }\end{array}$ & $\begin{array}{c}(6) \\
12 \text { months }\end{array}$ \\
\hline q0 & $\begin{array}{l}0.170^{+} \\
(0.110)\end{array}$ & $\begin{array}{c}0.0543 \\
(0.0819)\end{array}$ & $\begin{array}{r}-0.00827 \\
(0.0193)\end{array}$ & $\begin{array}{c}-0.00394 \\
(0.00862)\end{array}$ & $\begin{array}{l}-0.00250 \\
(0.00411)\end{array}$ & $\begin{array}{l}-0.00186 \\
(0.00404)\end{array}$ \\
\hline maturity & $\begin{array}{l}0.0000630^{+} \\
(0.0000421)\end{array}$ & & & & & \\
\hline convex & $\begin{array}{c}0.00215^{* * *} \\
(0.000179)\end{array}$ & & & & & \\
\hline Time-FE & $\mathrm{No}$ & Yes & Yes & Yes & Yes & Yes \\
\hline ISIN-FE & No & Yes & Yes & Yes & Yes & Yes \\
\hline $\mathrm{N}$ & 237 & 1206 & 16479 & 33026 & 48999 & 64073 \\
\hline
\end{tabular}


Table 9: French 10y yield and proxy of expected total size of APP (Nov 2014-Sept 2016)

Dependent variable: generic French 10y nominal yield. regression run on monthly data (Nov 2014-Sept 2016)

\begin{tabular}{lcccc}
\hline \hline & $(1)$ & $(2)$ & $(3)$ & $(4)$ \\
& Baseline & + ILS & + ESI & + Fiscal deficit \\
\hline D.Proxy Total size APP & $-1.442^{*}$ & $-1.183^{*}$ & $-1.316^{*}$ & $-1.572^{* *}$ \\
& $(0.701)$ & $(0.637)$ & $(0.673)$ & $(0.704)$ \\
& & & & \\
D. $E_{t}\left(\pi_{10 y}\right)$ & & 0.504 & $0.579^{+}$ & 0.445 \\
& $(0.348)$ & $(0.380)$ & $(0.391)$ \\
D.ESI & & & -0.0472 & -0.0532 \\
& & & $(0.0542)$ & $(0.0491)$ \\
D. $E_{t}(F D(n+1))$ & & & & $0.495^{* *}$ \\
& & & & $(0.225)$ \\
Constant & 0.0510 & 0.0415 & 0.0560 & $0.0934^{+}$ \\
& $(0.0553)$ & $(0.0526)$ & $(0.0506)$ & $(0.0540)$ \\
\hline Adjusted $R^{2}$ & 0.099 & 0.145 & 0.137 & 0.232 \\
Observations & 22 & 22 & 22 & 22 \\
\hline \hline Standard errors in parentheses & & & & \\
${ }^{*} p<0.10,{ }^{* *} p<0.05,{ }^{* * *} p<0.01$ & & & \\
& & & &
\end{tabular}

Table 10: Diff-in-diff panel regression

Dependent variable: Period return since 2 Jan 2015. Panel regressions run between 09/03/2015 (Start of the program) and 08/07/2015 (end of the sell-off period). Security-fixed effect and time-fixed effect not shown.

\begin{tabular}{lccc}
\hline \hline & $(1)$ & $(2)$ & $(3)$ \\
\hline eligible $\times$ selloff & $-0.0389^{* * *}$ & $-0.0314^{* * *}$ & $-0.0107^{*}$ \\
& $(0.00339)$ & $(0.00345)$ & $(0.00553)$ \\
maturity & & & \\
& & $0.0149^{* * *}$ & 0.00592 \\
& & $(0.00390)$ & $(0.00421)$ \\
convexity & & $0.108^{* * *}$ & $0.101^{* * *}$ \\
& & $(0.0189)$ & $(0.0177)$ \\
Eligible & & & $-0.0196^{* * *}$ \\
& & & $(0.00694)$ \\
Dummy Selloff & & & $-0.0229^{* * *}$ \\
& & & $(0.00446)$ \\
\hline Adjusted $R^{2}$ & 0.145 & 0.321 & 0.360 \\
Observations & 18513 & 18169 & 18169 \\
\hline \hline Standard errors in parentheses & & \\
${ }^{*} p<0.10,{ }^{* *} p<0.05,{ }^{* * *} p<0.01$ & &
\end{tabular}


Figure 5: Distribution of central bank purchase ratio $q t_{0, t, t}$

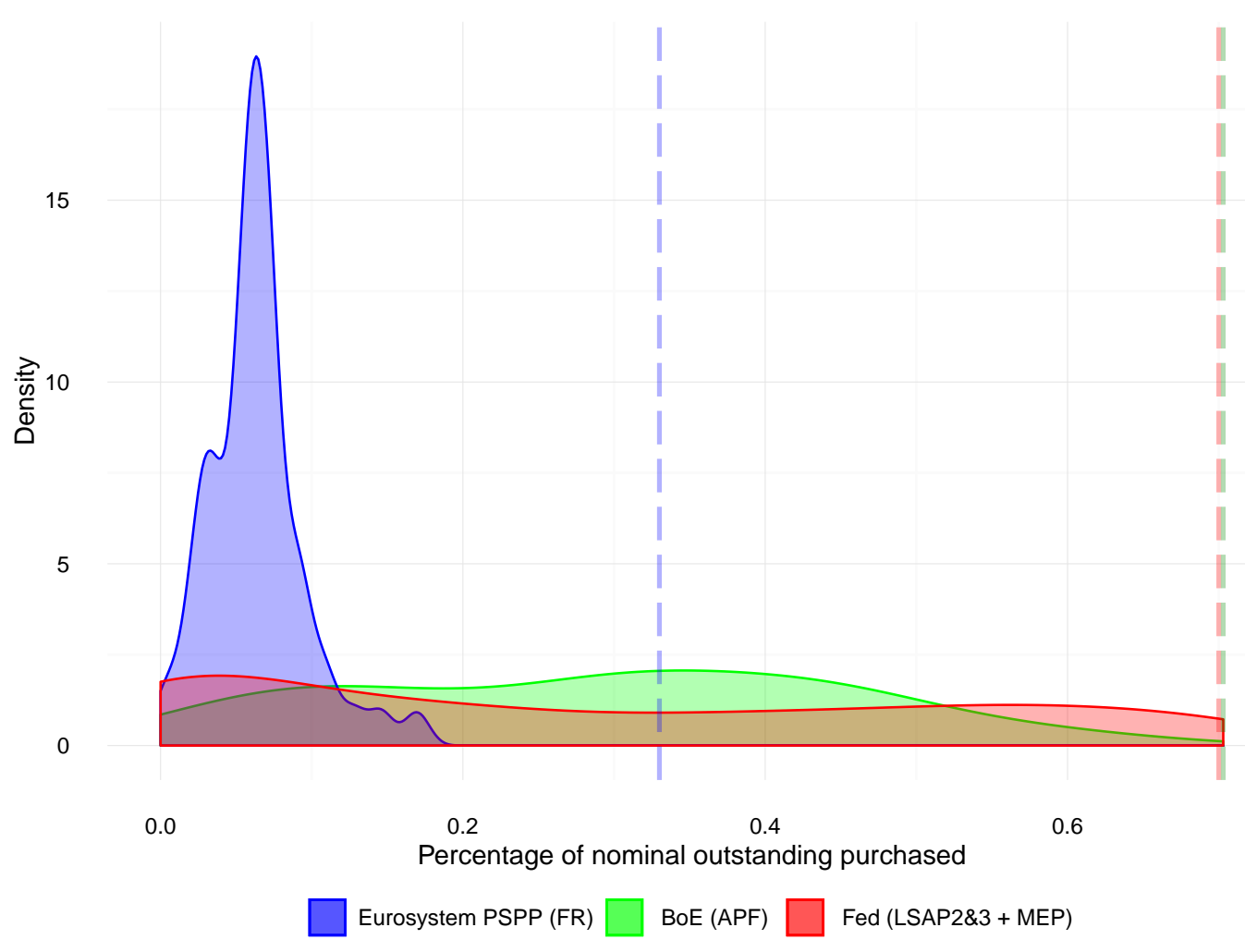

We compute here the ratio of central bank purchase over the nominal outstanding at the security level $\left(q t_{0, i, t}\right.$ ) - for the Fed (as of Dec 2014 at the end of all QE programs), the BoE (as of Jan 2016) and the Eurosystem (based on BDF data on French government bonds, as of 9th March 2016). Security-level data is from public data published by the NY Fed and Bank of England.

Purchases rules in the case of PSPP (buy approximately in proportion of the outstanding, foster market neutrality...) imply a tight distribution of the shares of bonds purchased, which is at odds with purchases from the Fed and the BoE. Vertical dashed lines correspond to the "issue limit" set by each central bank, $33 \%$ in the case of Eurosystem, $70 \%$ for both the Fed and the BoE. 
Figure 6: Daily purchase range during QE programs

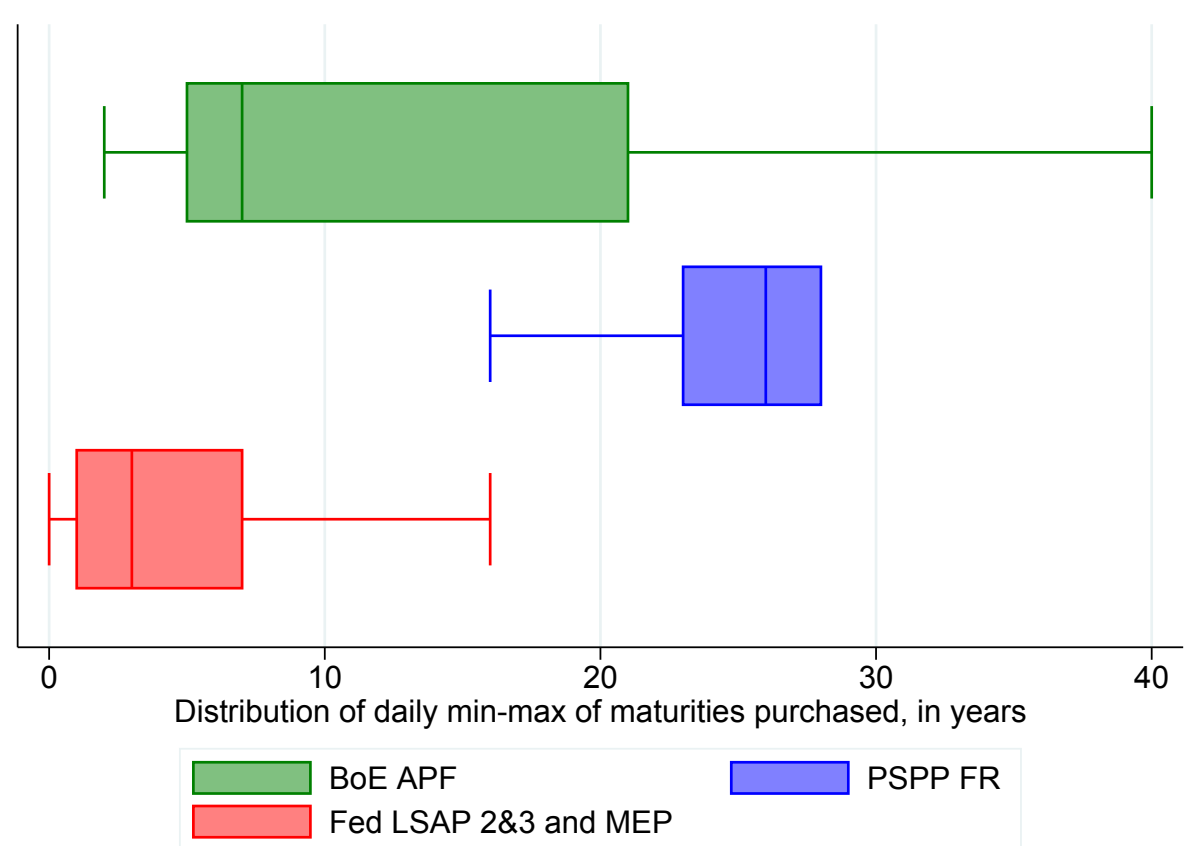

We compute for each central bank the purchase range in terms of maturity (maximum maturity minus minimum maturity purchased within the same day) of daily asset purchase programs transactions. The higher is the purchase range, the widest were the purchases along the curve. On the contrary, a short purchase range signals that purchases have been concentrated each day, on average, on a small segment of the curve. Ultimately, a maturity range of 0 would mean that every day, bonds of a unique maturity were purchased.

For the ECB, we use the purchases on the French bond market. The median is close to 27 years, meaning PSPP purchases were made on a very wide range of maturities. As the eligible range is between 2 and 30 years included, it means that every day purchased occurred almost for each maturity.

Sources: For the Fed, we use transaction data for QE2, MEP and QE3. For the BoE, the transactions of the $\mathrm{APF}$. 


\section{References}

Acharya, V. and Plantin, G. (2017). Monetary easing and financial instability. New York University and Science Po, mimeo.

Altavilla, C., Carboni, G., and Motto, R. (2015). Asset purchase programmes and financial markets: lessons from the euro area. Working Paper Series 1864, European Central Bank.

Andrade, P., Breckenfelder, J., De Fiore, F., Karadi, P., and Tristani, O. (2016). The ecb's asset purchase programme: an early assessment. European central Bank Working papers No 1956.

Andrés, J., López-Salido, J. D., and Nelson, E. (2004). Tobin's imperfect asset substitution in optimizing general equilibrium. Journal of Money, Credit, and Banking, 36(4):665-690.

Andritzky, J. R. (2012). Government Bonds and their Investors; What Are the Facts and Do they Matter? IMF Working Papers 12/158, International Monetary Fund.

Ang, A. (2014). Asset management: A systematic approach to factor investing. Oxford University Press.

Bernanke, B., Reinhart, V., and Sack, B. (2004). Monetary policy alternatives at the zero bound: An empirical assessment. Brookings papers on economic activity, 2004(2):1-100.

BIS (2016). Fixed income market liquidity.

Blattner, T. and Joyce, M. (2016). Net debt supply shocks in the euro area and the implications for qe. European central Bank Working papers No $195 \%$.

Boermans, M. A., Frost, J., and Bisschop, S. S. (2016). European bond markets: Do illiquidity and concentration aggravate price shocks? Economics Letters, 141:143 - 146.

Cahill, M. E., D’Amico, S., Li, C., and Sears, J. S. (2013). Duration risk versus local supply channel in Treasury yields: evidence from the Federal Reserve's asset purchase announcements. Technical report.

Campbell, J. Y. and Viceira, L. M. (2002). Strategic Asset Allocation: Portfolio Choice for Long-Term Investors. Number 9780198296942 in OUP Catalogue. Oxford University Press.

Carvalho, D. and Fidora, M. (2015). Capital inflows and euro area long-term interest rates. Journal of International Money and Finance, 54(C):186-204.

Chamley, C. and Polemarchakis, H. (1984). Assets, General Equilibrium and the Neutrality of Money. Review of Economic Studies, 51(1):129-138.

Cochrane, J. H. (2008). Comments on Bond Supply and Excess Bond Returns, by Robin Greenwood and Dimitri Vayanos. University of Chicago, (2).

Cochrane, J. H. (2009). Asset Pricing:(Revised Edition). Princeton university press.

Cochrane, J. H. (2011). Inside the Black Box: Hamilton, Wu, and QE2. Comments on James Hamilton and Jing Wu, "The Effectiveness of Alternative Monetary Policy Tools in a Zero Lower Bound Environment,", NBER Monetary Economics Program Meeting, March 4, 2011(2). 
Curdia, V., Ferrero, A., and Chen, H. (2012). The Macroeconomic Effects of Large-Scale Asset Purchase Programs. Technical report.

Curdia, V. and Woodford, M. (2010). The Central Bank Balance Sheet as an Instrument of Monetary Policy. Technical report.

D'Amico, S., Fan, R., and Kitsul, Y. (2014). The scarcity value of Treasury collateral: Repo market effects of security-specific supply and demand factors. Finance and Economics Discussion Series 2014-60, Board of Governors of the Federal Reserve System (U.S.).

D'Amico, S. and King, T. B. (2013). Flow and stock effects of large-scale treasury purchases: Evidence on the importance of local supply. Journal of Financial Economics, 108(2):425-448.

Doran, D., Dunne, P., Monks, A., and O'Reilly, G. (2013). Was the Securities Markets Programme Effective in Stabilizing Irish Sovereign Yields? Research Technical Papers 07/RT/13, Central Bank of Ireland.

Duffie, D. (1996). Special Repo Rates. Journal of Finance, 51(2):493-526.

Duffie, D. and Krishnamurthy, A. (2016). Passthrough efficiency in the fed's new monetary policy setting. presented at the 2016 jackson hole symposium of the federal reserve bank of kansas city.

Eggertsson, G. B. and Woodford, M. (2003). The Zero Bound on Interest Rates and Optimal Monetary Policy. Brookings Papers on Economic Activity, 34(1):139-235.

Eichengreen, B. J. and Gupta, P. D. (2014). Tapering talk : the impact of expectations of reduced federal reserve security purchases on emerging markets. Policy Research Working Paper Series 6754, The World Bank.

Eser, F. and Schwaab, B. (2016). Evaluating the impact of unconventional monetary policy measures: Empirical evidence from the ECBs Securities Markets Programme. Journal of Financial Economics, 119(1):147-167.

Gagnon, J., Raskin, M., Remache, J., and Sack, B. (2011). Large-scale asset purchases by the Federal Reserve: did they work? Economic Policy Review, (May):41-59.

Garbade, K. D. and Rutherford, M. (2007). Buybacks in Treasury cash and debt management. Technical report.

Ghysels, E., Idier, J., Manganelli, S., and Vergote, O. (2014). A high frequency assessment of the ECB securities markets programme. Working Paper Series 1642, European Central Bank.

Greenwood, R. and Vayanos, D. (2014). Bond Supply and Excess Bond Returns. Review of Financial Studies, 27(3):663-713.

Hamilton, J. D. and Wu, J. C. (2012). The Effectiveness of Alternative Monetary Policy Tools in a Zero Lower Bound Environment. Journal of Money, Credit and Banking, 44:3-46.

Hayashi, F. (2016). Affine term structure pricing with bond supply as factors. FRB Atlanta CQER Working Paper 2016-1, Federal Reserve Bank of Atlanta. 
Joyce, M., Lasaosa, A., Stevens, I., and Tong, M. (2010). The financial market impact of quantitative easing. Bank of England working papers 393, Bank of England.

Joyce, M. A. and Tong, M. (2012). Qe and the gilt market: a disaggregated analysis*. The Economic Journal, 122(564):F348-F384.

Kandrac, J. and Schlusche, B. (2013). Flow effects of large-scale asset purchases. Economics Letters, 121(2):330-335.

Kimura, T. and Small, D. (2004). Quantitative monetary easing and risk in financial asset markets. Finance and Economics Discussion Series 2004-57, Board of Governors of the Federal Reserve System (U.S.).

King, T. B. (2013). A portfolio-balance approach to the nominal term structure.

Koijen, R., Koulischer, F., Nguyen, B., and Yogo, M. (2016). Quantitative easing in the euro area: The flow of risk and the impact on asset prices. Banque de France Working papers series, No 601.

Krishnamurthy, A. (2002). The bond/old-bond spread. Journal of Financial Economics, 66(2-3):463 - 506. Limits on Arbitrage.

Krishnamurthy, A. and Vissing-Jorgensen, A. (2011). The Effects of Quantitative Easing on Interest Rates: Channels and Implications for Policy. NBER Working Papers 17555, National Bureau of Economic Research, Inc.

Levy, H. and Markowitz, H. M. (1979). Approximating expected utility by a function of mean and variance. The American Economic Review, pages 308-317.

Li, C. and Wei, M. (2014). Term Structure Modeling with Supply Factors and the Federal Reserve's Large Scale Asset Purchase Programs. Finance and Economics Discussion Series 2014-7, Board of Governors of the Federal Reserve System (U.S.).

Meaning, J. and Zhu, F. (2011). The impact of recent central bank asset purchase programmes. BIS Quarterly Review.

Miles, D. and Schanz, J. (2014). The relevance or otherwise of the central bank's balance sheet. Journal of International Economics, 92, Supplement 1(0):S103 - S116. 36th Annual \{NBER\} International Seminar on Macroeconomics.

Modigliani, F. and Sutch, R. (1967). Debt management and the term structure of interest rates: an empirical analysis of recent experience. The journal of political economy, pages 569-589.

Neely, C. J. (2014). Lessons from the taper tantrum. Economic Synopses, (2).

Reinhart, V. and Sack, B. (2000). The Economic Consequences of Disappearing Government Debt. Brookings Papers on Economic Activity, 31(2):163-220.

Tobin, J. (1958). Liquidity Preference as Behavior Towards Risk. Review of Economic Studies, 25(2):65-86.

Tobin, J. (1969). A General Equilibrium Approach to Monetary Theory. Journal of Money, Credit and Banking, 1(1):15-29. 
Trebesch, C. and Zettelmeyer, J. (2014). ECB Interventions in Distressed Sovereign Debt Markets: The Case of Greek Bonds. Technical report.

Vayanos, D. and Gromb, D. (2010). Limits of Arbitrage: The State of the Theory. FMG Discussion Papers dp650, Financial Markets Group.

Vayanos, D. and Vila, J.-L. (2009). A preferred-habitat model of the term structure of interest rates.

Wallace, N. (1981). A modigliani-miller theorem for open-market operations. The American Economic Review, 71(3):267-274.

Warnock, F. E. and Warnock, V. C. (2005). International capital flows and U.S. interest rates. Technical report. 


\section{A Appendix}

\section{A.1 Key announcements of the Eurosystem purchase programs (Aug 2014-}

March 2016)

\begin{tabular}{|c|c|c|}
\hline Date & Type & Announcement details \\
\hline 22 Aug 2014 & Speech, Jackson Hole & $\begin{array}{l}\text { Pres. Draghi insists on disanchoring risk and } 5 y 5 y \text { inflation } \\
\text { swap below } 2 \% \text {, says: "The Governing Council will acknowl- } \\
\text { edge these developments and within its mandate will use all } \\
\text { the available instruments needed to ensure price stability over } \\
\text { the medium term" }\end{array}$ \\
\hline 4 Sep 2014 & ECB Gov. Council & $\begin{array}{l}\text { Announcement of a first round of asset purchase, focused on } \\
\text { ABS (ABSPP) and covered bonds (CBPP3). Pres. Draghi: } \\
\text { "QE was discussed" "The second aim is to steer, significantly } \\
\text { steer, the size of our balance sheet towards the dimensions it } \\
\text { used to have at the beginning of } 2012 \text { " }\end{array}$ \\
\hline 22 Jan 2015 & ECB Gov. Council & $\begin{array}{l}\text { "In March } 2015 \text { the Eurosystem will start to purchase euro- } \\
\text { denominated investment-grade securities issued by euro area } \\
\text { governments and agencies and European institutions in the } \\
\text { secondary market. The purchases of securities issued by euro } \\
\text { area governments and agencies will be based on the Eurosystem } \\
\text { NCBs' shares in the ECB's capital key." "Under this expanded } \\
\text { programme, the combined monthly purchases of public and } \\
\text { private sector securities will amount to } € 60 \text { billion." }\end{array}$ \\
\hline 9 Mar 2015 & ECB & Start of the PSPP purchase operations \\
\hline 2 Jul 2015 & ECB & Extension of PSPP eligibility to several agencies \\
\hline 3 Sept 2015 & ECB Gov. Council & Issue limit increased from $25 \%$ to $33 \%$ \\
\hline 10 Dec 2015 & ECB Gov. Council & $\begin{array}{l}\text { Extension of Asset Purchase Programme. Pres Draghi: "Sec- } \\
\text { ond, as regards non-standard monetary policy measures, we } \\
\text { decided to extend the asset purchase programme (APP). The } \\
\text { monthly purchases of } € 60 \text { billion under the APP are now } \\
\text { intended to run until the end of March 2017, or beyond, if } \\
\text { necessary" }\end{array}$ \\
\hline 10 March 2016 & ECB Gov. Council & $\begin{array}{l}\text { Expansion of monthly purchases to } € 80 \text { billion. Pres Draghi: } \\
\text { "Second, we decided to expand the monthly purchases under } \\
\text { our asset purchase programme from } € 60 \text { billion at present to } \\
€ 80 \text { billion. They are intended to run until the end of March } \\
2017 \text {, or beyond, if necessary" }\end{array}$ \\
\hline
\end{tabular}




\section{A.2 French Public agencies eligible to the Eurosystem asset purchase, as of 9th Mar 2016}

https ://www.ecb.europa.eu/mopo/implement/omt/html/pspp.en.html

\begin{tabular}{|l|l|}
\hline Eligible since & Agency \\
\hline 22 jan 2015 & Caisse d'amortissement de la dette sociale (CADES) \\
22 jan 2015 & Union Nationale Interprofessionnelle pour l'Emploi dans l'Industrie et le Commerce \\
& (UNEDIC) \\
22 jan 2015 & Bpifrance Financement SA (OSEOFI) \\
22 jan 2015 & ACOSS \\
22 jan 2015 & Caisse des Dépôts et Consignations (CDCEPS) \\
22 jan 2015 & Agence Francaise de Développement (AFD) \\
2 Jul 2015 & SNCF Réseau (RESFER) \\
2 Jul 2015 & Caisse Nationale des Autoroutes (CNA) \\
\hline
\end{tabular}

\section{A.3 Public data sources}

\begin{tabular}{|l|l|}
\hline Data & Source \\
\hline Bond clean price and yield & Bloomberg \\
Bond nominal outstanding & Bloomberg and subset of CSDB \\
Stripping activity & Agence France Tresor, Reuters \\
Other bonds characteristics & Bloomberg \\
Rich vs cheap assesment & Bloomberg BVAL function \\
Cheapest-to-deliver & Eurex \\
Repo special & BrokerTec/ICAP \\
Poll on ECB balance sheet & Reuters ${ }^{30}$ and Bloomberg \\
Size of the current ECB balance sheet & ECB \\
Size of the PSPP program & ECB \\
Inflation forward & Inflation-linked swaps from Bloomberg \\
Short term rate path forward & OIS contracts from Bloomberg \\
Fiscal deficit forecast & SPF poll from Bloomberg, Agence France Tresor, PLF (Projet \\
Economic sentiment indicator (ESI) & de Loi de finances), PSF (Programme de stabilité financière) \\
\hline
\end{tabular}

\footnotetext{
${ }^{30}$ We acknowledge the help of Vanessa Young and Thomson Reuters economic poll team
} 


\section{B Technical appendix: extracting the "expected stock"}

In this section, we detail the sources and methodology used to recover the expected stock that we note $E_{t}\left(Q E T O T_{T}\right)$, corresponding to the total size of APP expected by market participants.

Unfortunately, to our best knowledge, no direct measure of $E_{t}\left(Q E T O T_{T}\right)$ is available at a regular basis ${ }^{31}$. In polls data, variability of the questions sometimes asked about the programs' size further complicates the comparability and the consistency of the answers through time, making difficult to build any time series. In contrast, all polls that we know asked relatively precise questions about the size of the future balance sheet of the ECB, on a more regular basis. Thus, we infer our proxy for $E_{t}\left(Q E T O T_{T}\right)$ from expectation of balance sheet changes, using the following method:

$$
E_{t}\left(Q E T O T_{T}\right)=\left[E_{t}\left(B S_{T}\right)-B S_{t}\right]+Q E T O T_{t}-E_{t}\left(\Delta_{t, T}(O T H)\right)
$$

The expectations in $t$ over the total size of QE in $T$ will be equal to the existing size of QE in $t Q E T O T_{t}$ plus the changes expected between $t$ and $T$ of the central bank's balance sheet, corrected from other changes that are unrelated to QE. In practice we set T as the longest forecast horizon (2017), as PSPP has been announced to last until Sept 2016, then March 2017, and will possibly be further extended through 2017. $E_{t}\left(\Delta_{t, T}(O T H)\right)$ is the expected variations of the balance sheet that are not related to $\mathrm{QE}$.

We used in the paper the longest and the most available data, from Thomson Reuters polls. We then cross-check our results with some polls conducted by Bloomberg when and as long it was possible. Some specific questions about other balance sheets movers such as LTROs allow us to further test the robustness of our measure.

\section{B.1 Thomson Reuters polls}

Ahead of each ECB Governing Council, Thomson Reuters conducts a poll of professional forecasters on their monetary policy expectations, generally on policy rates and take ups to the next refinancing operations. From November 2014, Reuters also asked about the probability the Eurosystem would embark in an asset purchase program, and for which size, most of the time indirectly as a change expected in the size of the ECb balance sheet. Questions were asked in the following form: "What is your forecast for change in the ECB's balance sheet by end 2016/2017?" or "What is your forecast for the ECB's balance sheet in total by end 2016/2017"

We use the median of these expectations of balance sheet change $E_{t}\left(B S_{T}\right)$ to compute a proxy for the total size of the purchases at the end of the program $E_{t}\left(Q E T O T_{T}\right)$, at the final date $T$. In practice we set $T$ as the longest forecast horizon (2017).

As we said, there are others drivers than QE of the central bank balance sheet size. In particular, long-term refinancing operations (LTROs) can contribute to the upside (take-ups at future refinancing operations) as well as to the downside (gradual reimbursements of the past operations).

As a first approximation, we set $E_{t}\left(\Delta_{t, T}(O T H)\right)$ equal to zero, assuming these two forces cancel out each others, and that other purchases do not contribute to a large extent to the ECB balance sheet variations. Put differently we assume that PSPP is the main driver of the variations of ECB's balance sheet size. These assumptions sounds reasonable in the sense that we actually observe that the share of LTROs tends to remain approximately the same since mid-2014, new operations replacing maturing ones, while purchases in ABS and covered bonds were seen as difficult to implement for significant amounts.

Table 11 details the information extracted from 14 consecutive polls conducted by Reuters, generally a week ahead from each Governing Council meeting.

${ }^{31}$ Blattner and Joyce (2016) use Bloomberg polls until Jan 2015 
Table 11: Data from Reuters polls, in trillions Eur

\begin{tabular}{lrrrr}
\hline \hline Date of polls & $E_{t}\left(B S_{T}\right)$ & $B S_{t}$ & QETOT $_{t}$ & $E_{t}\left(\right.$ QETOT $\left._{T}\right)$ \\
\hline $11 / 24 / 2014$ & 2.98 & 2.03 & 0.01 & 0.96 \\
$01 / 09 / 2015$ & 3.17 & 2.17 & 0.03 & 1.03 \\
$02 / 23 / 2015$ & 3.27 & 2.17 & 0.05 & 1.15 \\
$04 / 06 / 2015$ & 3.43 & 2.33 & 0.12 & 1.22 \\
$05 / 26 / 2015$ & 3.30 & 2.40 & 0.22 & 1.12 \\
$07 / 10 / 2015$ & 3.30 & 2.51 & 0.32 & 1.12 \\
$08 / 27 / 2015$ & 3.36 & 2.55 & 0.40 & 1.21 \\
$09 / 20 / 2015$ & 3.37 & 2.60 & 0.46 & 1.22 \\
$10 / 22 / 2015$ & 3.39 & 2.64 & 0.51 & 1.26 \\
$11 / 25 / 2015$ & 3.50 & 2.69 & 0.58 & 1.39 \\
$01 / 19 / 2016$ & 3.70 & 2.78 & 0.68 & 1.60 \\
$03 / 01 / 2016$ & 3.83 & 2.85 & 0.77 & 1.75 \\
$04 / 01 / 2016$ & 4.00 & 2.90 & 0.88 & 1.98 \\
$05 / 27 / 2016$ & 4.10 & 3.00 & 1.00 & 2.10 \\
\hline \hline
\end{tabular}

\section{B.2 Robustness: cross-checking with available Bloomberg data}

Bloomberg also surveys professional forecasters about the ECB monetary policy, including a question on expected LTROs and TLTROs, and other purchases program that PSPP, ie. ABSPP and CBPP3, items that were not available in Reuters polls.

Instead of setting $E_{t}\left(\Delta_{t, T}(O T H)\right)$ equal to zero, we can verify, when available, that our approximation is correct, and unaffected by a possible change in LTROs expectations.

As a result, it allows us to compute $E_{t}\left(Q E T O T_{T}\right)$ in the following way :

$$
E_{t}\left(Q E T O T_{T}\right)=\left[E_{t}\left(B S_{T}\right)-B S_{t}\right]+Q E T O T_{t}-E_{t}\left(\Delta_{t, T}(L T R O)\right)-E_{t}\left(\Delta_{t, T}(T L T R O)\right)
$$

As for the other expected variations, we compute the variations related to existing and future LTROs and TLTROs. For LTROs we use the redemption schedule of pas operations, to be paid back entirely by March 2015 (on January 2015 at the latest for LTRO 1 and on March 2015 at the latest for LTRO 2). For TLTROs, we compute the total variation contained in polls answers to the questions: "How much will banks take up in the ECB's TLTROs in total?" "How much liquidity will the ECB provide through TLTROs?" or "How much of the Balance Sheet expansion will be due to TLTROs?"

$E_{t}\left(A B S C B_{T}\right)$ concerns the variations caused by the ABSPP and CBPP3 programs, and is obtained from the following questions: "How much do you expect the ECB to spend on ABS purchases/Covered Bonds purchases?" "How much liquidity will the ECB provide through ABS/Covered Bonds?" or "How much of total purchases will be in the following asset classes?".

Table 12 gives the results obtained. Here again, we have the same reduction in the expected total size of APP during Spring 2015. 
Table 12: Data from Bloomberg polls, in trillions Eur

\begin{tabular}{|c|c|c|c|c|c|c|c|c|}
\hline Poll & $E_{t}\left(B S_{T}\right)$ & $B S_{t}$ & $Q E T O T_{t}$ & $E_{t}\left(\Delta_{t, T}(L T R O)\right)$ & $E_{t}\left(\Delta_{t, T}(T L T R O)\right)$ & $E_{t}\left(Q E T O T_{T}\right)$ & $E_{t}\left(P S P P_{T}\right)$ & $E_{t}\left(A B S C B_{T}\right)$ \\
\hline$\overline{09 / 14 / 2014}$ & & 2.01 & 0 & -0.36 & 0.58 & & & 0.41 \\
\hline $10 / 12 / 2014$ & 2.64 & 2.05 & 0 & -0.32 & 0.49 & 0.41 & 0.06 & 0.35 \\
\hline $11^{\prime} / 17^{\prime} / 2014$ & 2.88 & 2.03 & 0.01 & -0.29 & 0.32 & 0.83 & 0.56 & 0.27 \\
\hline $12 / 15 / 2014$ & 3.03 & 2.04 & 0.02 & -0.27 & 0.37 & 0.92 & 0.59 & 0.33 \\
\hline $01 / 19 / 2015$ & & 2.02 & 0.03 & -0.21 & & $0.91^{*}$ & 0.59 & $0.33^{*}$ \\
\hline $03 / 16 / 2015$ & 3.20 & 2.13 & 0.06 & -0.08 & 0.15 & 1.06 & 0.85 & 0.17 \\
\hline $04 / 26 / 2015$ & 3.40 & 2.35 & 0.13 & 0 & 0.19 & 0.99 & 0.79 & 0.20 \\
\hline $06 / 14 / 2015$ & 3.41 & 2.42 & 0.24 & 0 & 0.21 & 1.03 & 0.82 & 0.19 \\
\hline $07 / 21 / 2015$ & 3.30 & 2.52 & 0.34 & 0 & & & & \\
\hline $08 / 16 / 2015$ & 3.30 & 2.54 & 0.38 & 0 & & & & \\
\hline
\end{tabular}

(*: here, we assume ABS and Covered Bonds purchases expectations did not change between December 2015 and January 2015)

Our measures are consistent, too, with totally different questions, more qualitative, asked on the probability that the ECB would stop early its purchase program, and taper its purchases. The ECB initially commited to purchase 60 bn Eur a month until September 2016 (ie. 19 months). In the graph below, we show that the total duration of the program was increasingly perceived from March 2015 as revisable to the downside. Bloomberg discontinued the question in its June 2015 poll, but in September 2015, a quasi-unanimity (80\%) of respondents expected the ECB to actually extend QE after September 2016.

Figure 7: ECB balance sheet size and contribution of each program

PSPP tends to be the main driver of the increase of the ECB balance sheet, due to refinancing operations cancelling out (MRO and LTROs replaced by TLTROs), and gradual maturing of the SMP holding that almost cancels out the effect of amounts of purchases in ABSPP and CBPP.

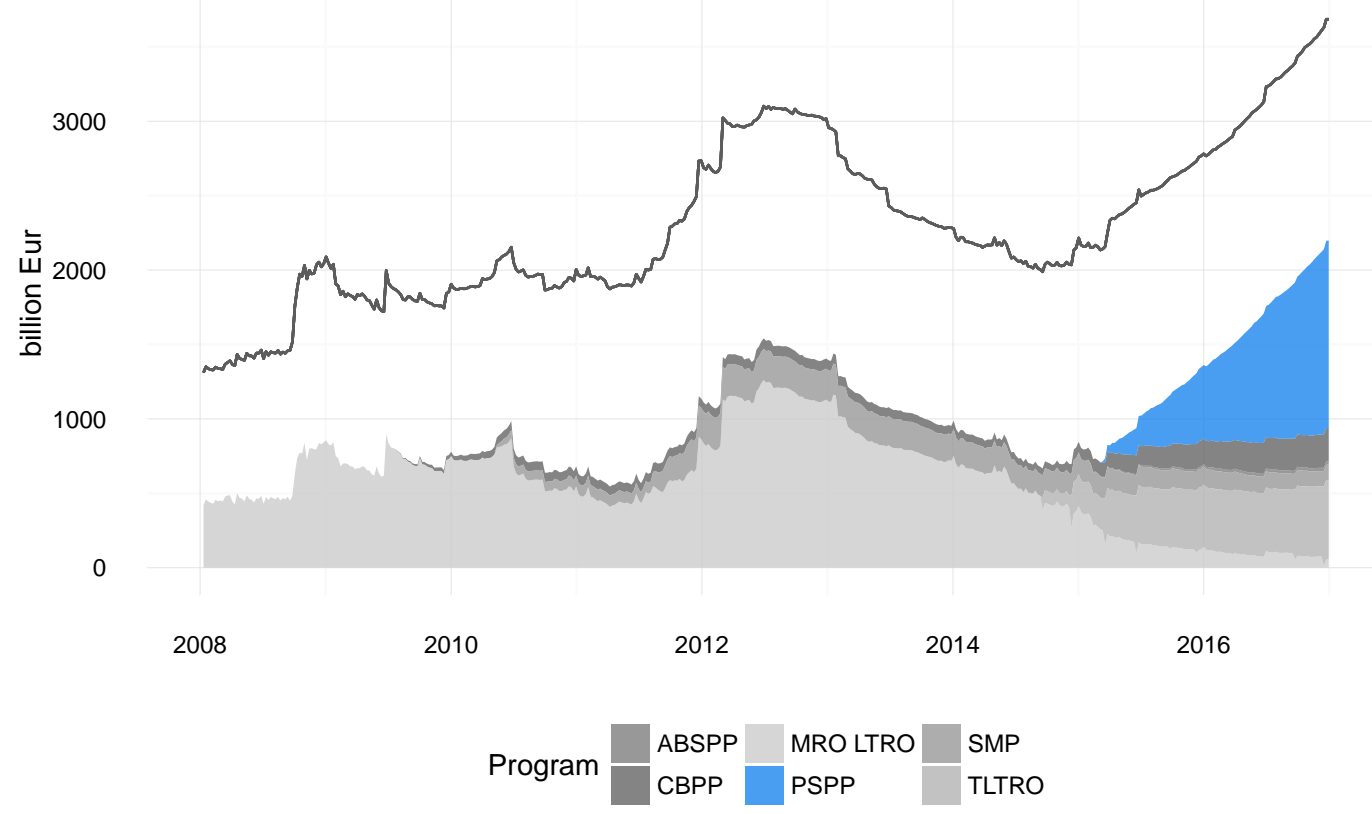


Figure 8: Distribution of SPF answers in polls conducted by Bloomberg in March, April and June 2015 Question asked: "When will the ECB start tapering QE?"

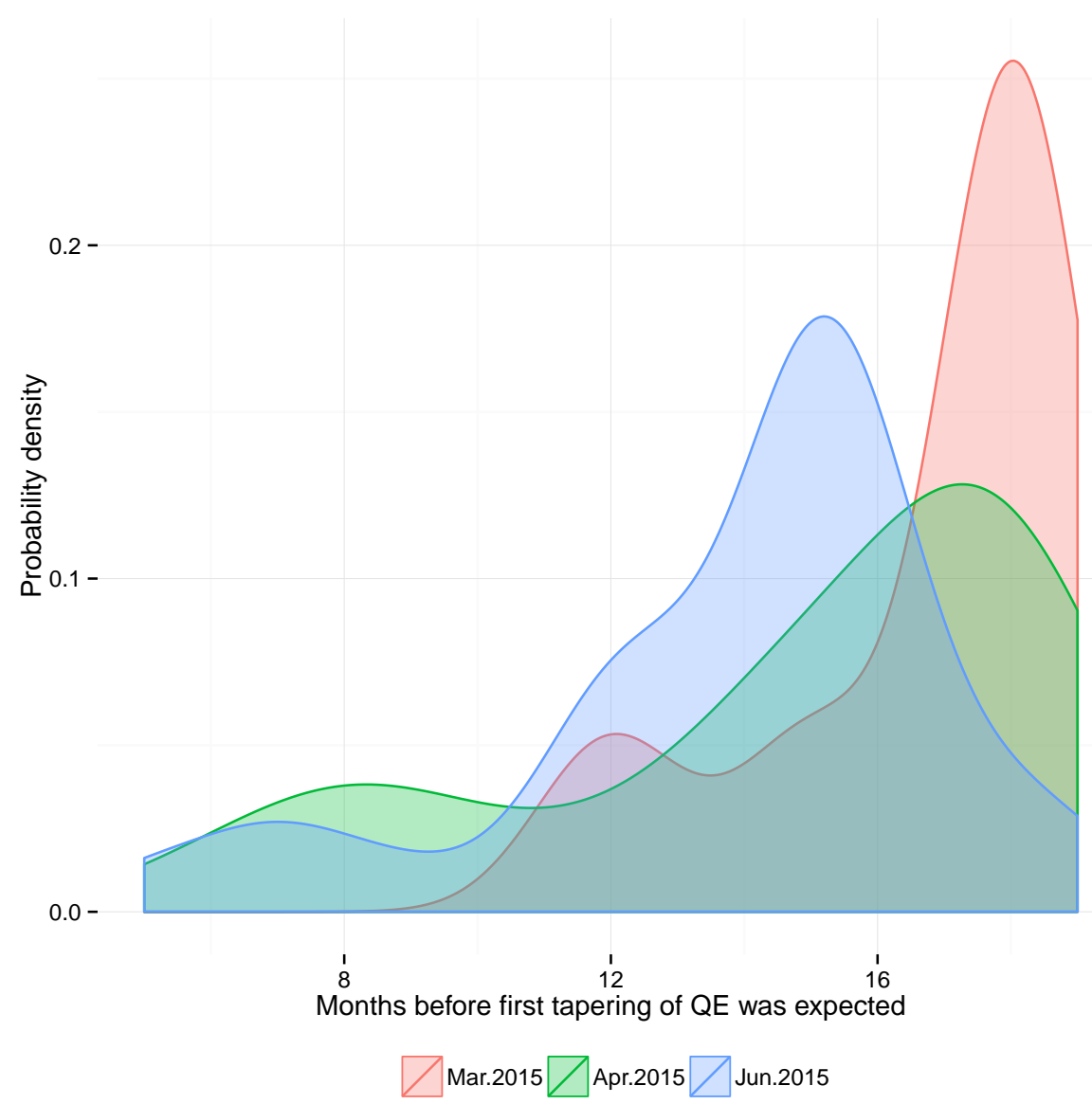

In March 2015, the ECB announcement was clear on both the pace (60 billion euros a month) and the timeline of the program ("Purchases intended to be carried out until at least September 2016")- ie. 19 months of purchases. The "tapering" question was asked during three months from March 2015, and then discontinued. In September 2015 a quasi-unanimity (80\%) of respondents expected that the ECB will actually extend QE after September 2016.

Average number of respondents: $\approx 22$ 


\section{A simple mean-variance counterfactual}

Our empirical study pointed out a significant correlation between bond supply and bond price, that we related to the existence of frictions, such as imperfect substituability, incomplete portfolio rebalancing and risk aversion (which we presume to be low in Euro area at the time of implementation of PSPP).

In the following, we run a simple exercise within a workhorse mean-variance portfolio optimization model, where bond supply is held by a unique investor. Asset purchases will affect its holding, as central bank will exchange bonds against reserves, and as such tilt the investor's portfolio toward less risky reserves. Returns must then adjust to accommodate the new asset allocation. This can be seen as a frictionless, simplified version of more sophisticated portfolio rebalancing models a la Vayanos Vila that would be sufficient to generate a prediction of in terms of bond returns change in response of asset purchases, as in Reinhart and Sack (2000) and Andritzky (2012).

Calibrating this model for the Euro area PSPP, we are aiming to see whether such a simplified model would be able to fit the magnitude of effects we found. This will give us a theoretical benchmark and a counterfactual in absence of frictions. If we were to find smaller price impact of our PSPP simulation, this would give an idea of the respective importance of frictions in the effects of asset purchases.

\section{C.1 Investor's optimization program}

We consider a single investor who maximizes the expected utility of his next period wealth:

$$
\max E_{t}\left[U\left(W_{t+1}\right)\right]
$$

Assuming the utility function is quadratic (as it is frequently the case in the literature for the sake of tractability), $U\left(W_{t+1}\right)$ is of the following form :

$$
\begin{gathered}
U\left(W_{t+1}\right)=W_{t+1}-b \cdot W_{t+1}^{2} \\
E_{t}\left[U\left(W_{t+1}\right)\right]=E_{t}\left[W_{t+1}\right]-b \cdot E_{t}\left[W_{t+1}^{2}\right]
\end{gathered}
$$

This type of expected utility maximization is interpretable as a trade-off between mean and variance (See for instance Levy and Markowitz (1979)) where $b$ is a coefficient of absolute risk aversion ${ }^{32}$.

Investor's wealth is invested in a portfolio $P$ of $N$ risky assets, represented by a weights vector $\mathbf{w}_{t}$. There will be no perfectly riskless asset, but reserves (asset 1) invested at the interbank rate.

$$
\mathbf{w}_{t}=\left(\begin{array}{c}
w_{1, t} \\
w_{2, t} \\
\vdots \\
w_{N, t}
\end{array}\right) ; \boldsymbol{E}_{t}\left[\boldsymbol{R}_{\boldsymbol{t + 1}}\right]=\left(\begin{array}{c}
E_{t}\left[R_{1, t+1}\right] \\
E_{t}\left[R_{2, t+1}\right] \\
\vdots \\
E_{t}\left[R_{N, t+1}\right]
\end{array}\right) ; \boldsymbol{\Sigma}_{t}=\left[\begin{array}{ccc}
\sigma_{1, t}^{2} & \sigma_{i j, t} & \ldots \\
\sigma_{i j, t} & \sigma_{i, t}^{2} & \ldots \\
\vdots & \vdots & \sigma_{N, t}^{2}
\end{array}\right] ; \boldsymbol{\iota}=(1, \ldots, 1)
$$

\footnotetext{
${ }^{32}$ Maximizing $E_{t}\left[W_{t+1}\right]-b . E_{t}\left[W_{t+1}^{2}\right]$ implies, for a given target of expected wealth $\left.E_{t}\left[W_{t+1}\right)\right]=k$, a preference for wealth $W_{t+1}$ minimizing $E_{t}\left[W_{t+1}^{2}\right]$, or, equivalently, minimizing $V\left(W_{t+1}\right)=E_{t}\left[W_{t+1}^{2}\right]-k^{2}$. As a result, maximizing the expected utility of the investor's wealth is equivalent to maximizing the mean $E[X]$ over the variance $V(W)$.
} 
Portfolio return is $R_{t+1}^{P}=\mathbf{w}_{t}^{\prime} \mathbf{R}_{t}$, and thus next period wealth is:

$$
E_{t}\left[W_{t+1}\right]=E_{t}\left[W_{t} \cdot\left(1+R_{t, t+1}^{P}\right)\right]=W_{t} \cdot\left(1+E_{t}\left[R_{t, t+1}^{P}\right]\right)
$$

Maximizing net period wealth rewrites (weights sum up to 1):

$$
\begin{gathered}
\max \mathbf{w}_{t}^{\prime} \mathbf{E}_{\mathbf{t}}\left[\mathbf{R}_{\mathbf{t}+\mathbf{1}}\right]-\frac{b}{2} \mathbf{w}_{t}^{\prime} \boldsymbol{\Sigma}_{t} \mathbf{w}_{t} \\
\text { s.t } \mathbf{w}_{t} \iota=1
\end{gathered}
$$

Arbitrageurs optimizing this kind of mean-variance problems are at the heart of Vayanos and Vila type of models. When weights are unconstrained, solution of this maximization problem with no riskless asset is Campbell and Viceira (2002)):

$$
\mathbf{w}_{t}^{\star}=\frac{1}{b} \boldsymbol{\Sigma}_{t}^{-1}\left(\mathbf{E}_{\mathbf{t}}\left[\mathbf{R}_{\mathbf{t}+\mathbf{1}}\right]-R_{1, t+1} \iota\right)-\boldsymbol{\Sigma}_{t}^{-1} \sigma_{1, t}
$$

Where $R_{1, t+1}$ and $\sigma_{1, t}$ relates to the first asset that works as a benchmark in the absence of a pure riskless asset, and thus $\mathbf{E}_{\mathbf{t}}\left[\mathbf{R}_{\mathbf{t}+\mathbf{1}}\right]-R_{1, t+1} \iota$ is a vector of excess returns in respect to the first asset, interbank reserves.

In this exercise, we assume weights are known and correspond to the market capitalization or in other words, our single investor always clears the market (so his wealth is invested is reserves and bonds and match exactly the market outstanding). Rearranging, we can express expected excess returns implied by these weights.

$$
\mathbf{E}_{\mathbf{t}}\left[\mathbf{R}_{\mathbf{t}+\mathbf{1}}^{\star}\right]-R_{1, t+1} \iota=b . \boldsymbol{\Sigma}_{t} \mathbf{w}_{t}+b . \sigma_{1, t}
$$

Central bank's asset purchases (APP) is a supply shock that modifies the allocation of investors, replacing bonds with reserves. The new vector of weights $\mathbf{w}_{t}^{\prime}$ is:

$$
\mathbf{w}_{t}(\text { Pre-APP })=\left(\begin{array}{c}
w_{1, t} \\
w_{2, t} \\
\vdots \\
w_{N, t}
\end{array}\right) ; \mathbf{w}_{t}^{\prime}(\text { Post }-A P P)=\left(\begin{array}{c}
w_{1, t}+w q e_{1, t} \\
w_{2, t}-w q e_{2, t} \\
\vdots \\
w_{N, t}-w q e_{N, t}
\end{array}\right) ; \sum_{i=1}^{N} w q e_{i, t}=0
$$

In this framework, expected returns are directly linked to weights, scaled by risk aversion coefficient $b$.

The change in expected excess returns required to equilibrate a change in portfolio weights induced by APP from $\mathbf{w}_{t}$ to $\mathbf{w}_{t}^{\prime}$ simplifies $^{33}$ to:

$$
\Delta\left(\mathbf{E}_{\mathbf{t}}\left[\mathbf{R}_{\mathbf{t}+\mathbf{1}}^{\star}\right]-R_{1, t+1} \iota\right)=b . \boldsymbol{\Sigma}_{t}\left[\mathbf{w}_{\mathbf{t}}-\mathbf{w}_{\mathbf{t}}^{\prime}\right]
$$

\section{C.2 An application to the European PSPP}

We calibrate this framework to give theoretical estimation of the impact of the Eurosystem's PSPP on sovereign bond yields. Asset 1 corresponds to the excess reserves, invested at the Eonia rate, while assets 2 to $\mathrm{N}$ are portions of the sovereign bonds market. Each portion corresponds to a specific maturity bucket:

\footnotetext{
${ }^{33} b . \sigma_{1, t}$ being a constant
} 
2Y-3Y, 3Y-5Y, 5Y-7Y, 7Y-10Y, 10Y-15Y and 15Y-30Y. Returns and expected returns for each asset as well as the covariance matrix are computed using 7 years of weekly data(2007-2014) of Eonia rate for reserves and using Bank of America Merrill Lynch Total Return Indices for maturity buckets, that we annualized. Weights are computed from outstanding amounts of the sovereign debts of Italy, France, Germany and Spain, as of Q1 2015, just before the start of the PSPP, and the excess liquidity level prevailing at this date.

We calibrate the PSPP shock as an exchange of $10 \%$ of the bond outstanding against reserves, to be comparable with our empirical results. This corresponds approximately to the initial total size of the program (1.1 trn Eur). We assume that purchases are split accordingly to outstanding as announced by the ECB.

Table 13: Portfolio weights before and after APP shock

\begin{tabular}{ccccc} 
& \multicolumn{2}{c}{ Before APP } & \multicolumn{2}{c}{ After APP } \\
\cline { 2 - 5 } Asset & Q (bn EUR) & $\mathrm{w}(\%)$ & $\mathrm{Q}($ bn EUR) & $\mathrm{w}(\%)$ \\
\hline Reserves & 273 & 0.070 & 638 & 0.163 \\
$2-3$ & 489 & 0.125 & 440 & 0.112 \\
$3-5$ & 818 & 0.209 & 737 & 0.188 \\
$5-7$ & 616 & 0.157 & 555 & 0.142 \\
$7-10$ & 754 & 0.192 & 677 & 0.173 \\
$10-15$ & 412 & 0.105 & 370 & 0.095 \\
$15-30$ & 554 & 0.142 & 499 & 0.127 \\
\hline Sum & 3916 & 1 & 3916 & 1 \\
\hline \hline
\end{tabular}

We argued before, like Altavilla et al. (2015), that risk aversion in the Euro area was likely to be low at the time of inception of the program. For the risk aversion coefficient $b$, we analyze the sensitivity of our results to usual levels of 2,5 and 10, as advised for instance in Ang (2014).

In the following table, we show the results obtained with different levels of risk aversion. We provide the changes in expected returns and convert them in changes in yields, for the sake of comparison with our empirical results, that suggested an impact of -13 to $-25 \mathrm{bps}$, with larger effects for longer maturities.

Note that when price goes up, expected returns fall (and yields fall):

$$
E_{t}\left[R_{t+1}^{i}\right]=\frac{E_{t}\left[P_{t+1}^{i}\right]}{P_{t}^{i}}-1
$$

with $E_{t}\left[R_{t+1}^{i}\right]$ the expected return on the asset at date $\mathrm{t}$ for date $\mathrm{t}+1$ before the shock, $P_{t}^{i}$ the spot price of the asset before the shock, and $E_{t}\left[P_{t+1}^{i}\right]$ the expected price of the asset at date $\mathrm{t}$ for date $\mathrm{t}+1$. We denote similarly $E_{t}\left[R_{t+1}^{i^{\prime}}\right]$ the expected return on the asset at date $\mathrm{t}$ for date $\mathrm{t}+1$ after the shock and $P_{t}^{i^{\prime}}$ the spot price after the shock.

The model predicts, as we found, a fall in yields consecutive to the asset purchases, and larger effects for longer maturities, consistent with our findings. But the magnitude are almost 10 times lower than what we found, suggesting that on top of this frictionless counterfectual, the major part of what we found is related to frictions such as preferred habitat, scarcity, and imperfect arbitrage that cannot be explained in the model by risk aversion. 
Table 14: Expected return and yield changes in response to an APP shock

\begin{tabular}{lrrrrrr}
\hline \hline $\begin{array}{l}\text { risk aversion coeff. } \\
\text { (in bps) }\end{array}$ & 2 & & 5 & \multicolumn{2}{c}{10} \\
\hline $2-3$ & $\Delta\left(E_{t}\left[R_{t+1}\right]\right)$ & $\Delta\left(y_{t}\right)$ & $\Delta\left(E_{t}\left[R_{t+1}\right]\right)$ & $\Delta\left(y_{t}\right)$ & $\Delta\left(E_{t}\left[R_{t+1}\right]\right)$ & $\Delta\left(y_{t}\right)$ \\
$3-5$ & $-1,24$ & $-0,41$ & $-3,09$ & $-1,04$ & $-6,20$ & $-2,07$ \\
$5-7$ & $-2,67$ & $-0,53$ & $-6,68$ & $-1,33$ & $-13,37$ & $-2,65$ \\
$7-10$ & $-3,86$ & $-0,55$ & $-9,65$ & $-1,37$ & $-19,31$ & $-2,72$ \\
$10-15$ & $-4,89$ & $-0,54$ & $-12,21$ & $-1,34$ & $-24,44$ & $-2,66$ \\
$15-30$ & $-6,07$ & $-0,55$ & $-15,17$ & $-1,36$ & $-30,34$ & $-2,69$ \\
\hline \hline
\end{tabular}

\section{C.3 Methodology: Converting a change in expected return into a change in yield}

Over a short period of time, the price variation of a bond can be linked to the variation in yields using the following approximation (from a Taylor expansion at the first order):

$$
P_{t}^{i^{\prime}}-P_{t}^{i} \approx-D_{t}^{i} \cdot\left(y_{t}^{i^{\prime}}-y_{t}^{i}\right) \cdot P_{t}^{i}
$$

With $D_{t}^{i}$ the duration of the asset (here, assets are bonds so our risk measure is duration), $y_{t}^{i^{\prime}}$ the yield on the asset after the shock and $y_{t}^{i}$ the yield on the asset before the shock.

Thus, $P_{t}^{i^{\prime}} \approx\left[1-D_{t}^{i} \cdot\left(y_{t}^{i^{\prime}}-y_{t}^{i}\right)\right] . P_{t}^{i}$. Now, recall that $E_{t}\left[R_{t+1}^{i}\right] \approx \frac{E_{t}\left[P_{t+1}^{i}\right]}{P_{t}^{i}}-1$. After the shock, the expected return can be written $E_{t}\left[R_{t+1}^{i^{\prime}}\right]=\frac{E_{t}\left[P_{t+1}^{i}\right]}{P_{t}^{i^{\prime}}}-1$ and we have:

$$
E_{t}\left[R_{t+1}^{i^{\prime}}\right]-E_{t}\left[R_{t+1}^{i}\right] \approx \frac{E_{t}\left[P_{t+1}^{i}\right]}{P_{t}^{i^{\prime}}}-\frac{E_{t}\left[P_{t+1}^{i}\right]}{P_{t}} \approx E_{t}\left[P_{t+1}^{i}\right] \cdot\left(\frac{1}{\left[1-D_{t}^{i} \cdot\left(y_{t}^{i^{\prime}}-y_{t}^{i}\right)\right] \cdot P_{t}^{i}}-\frac{1}{P_{t}^{i}}\right)
$$

Rearranging, we have:

$$
y_{t}^{i^{\prime}}-y_{t}^{i} \approx \frac{1}{D_{t}^{i}} \cdot \frac{E_{t}\left[R_{t+1}^{i^{\prime}}\right]-E_{t}\left[R_{t+1}^{i}\right]}{1+E_{t}\left[R_{t+1}^{i^{\prime}}\right]}
$$

\section{More elements about the European bond sell off}

In this section, we provide narrative elements on the "tapering talks" about the ECB QE - ie. opinions that concurred to doubt the Eurosystem will implement its purchase program until the pre-announced end, in September 2016.

Divergence among the Governing council members Would the purchase program size announcements be revisable and data-dependent?

On February 5th 2015, Governing Council member Bostjan Jazbec expressed this view to the Wall Street Journal: "I understand it this way... Once the price mandate is fulfilled, we can end it earlier."

On April 7th 2015, this was made even clearer by the ECB Executive Board member Yves Mersch "If we were to see that this process brings us to our goal earlier, then we are naturally not so tied to our decisions that we could not adjust things" 34

\footnotetext{
${ }^{34}$ http://uk.reuters.com/article/uk-ecb-policy-mersch-idUKKBNOMY1IF20150407
} 
In the April 15th Governing Council Q\&A session, ECB President Mario Draghi reacted to this tapering hypothesis. "I'm quite surprised, frankly, by the attention that a possible early exit of the programme receives, when we've been in this programme only a month [...] it's like asking yourself, after $1 \mathrm{~km}$, are we going to finish [a] marathon?"

Strategic take-profit On April 21th, Bill Gross said German Bund was "the short of a lifetime, better that the Pound in 1993".

Purely macro view Inflation figure came better than expected in March with the Euro Area HICP at $+0.5 \%$, leading market participants to think that the objectives of the Eurosystem will be easier to meet, discouraging the ECB policymakers to complete the announced package.

Purely technical view Moves were reinforced by poor liquidity, amidst extreme positioning of investors. One way market with low volatility can create such large repricing, because a small move can hit VaR limits and trigger sell-offs.

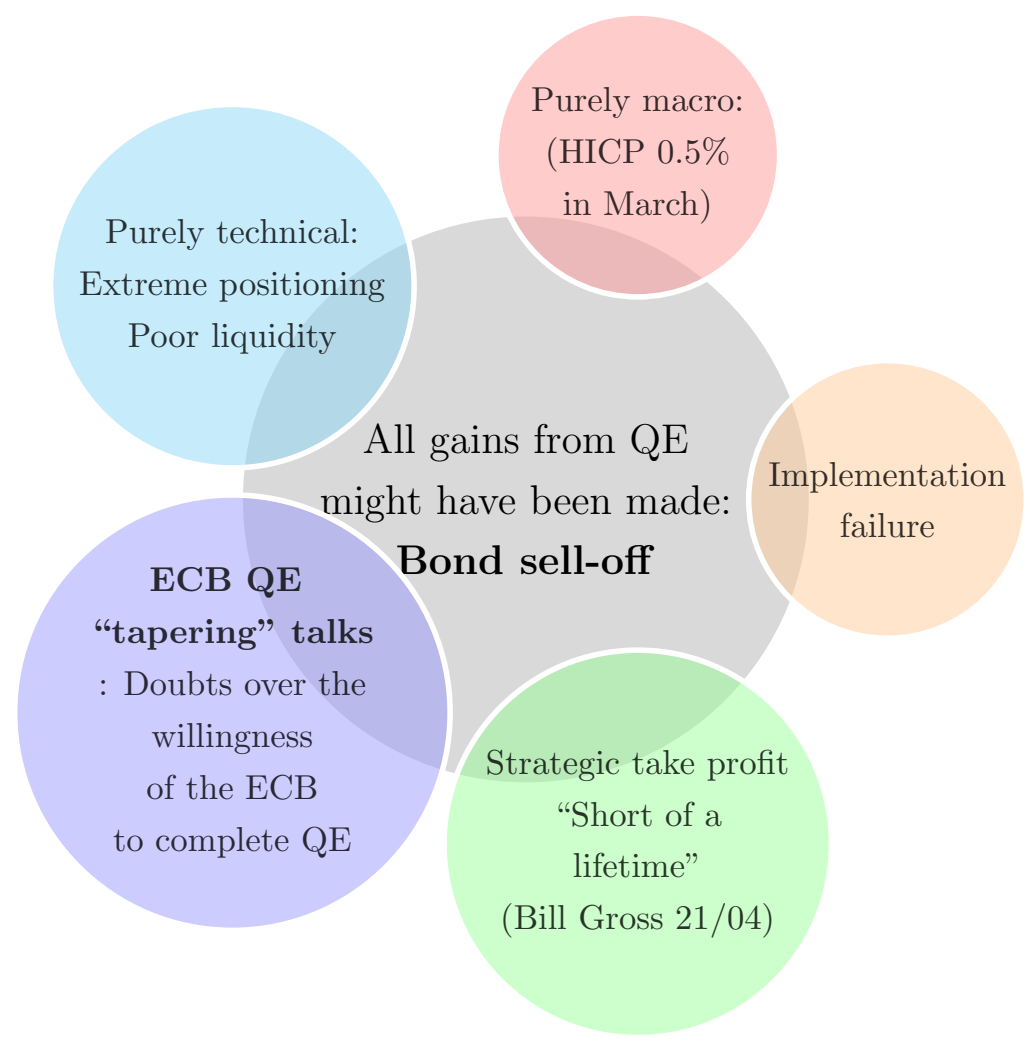

